Original Article

\title{
Assessment of land use cover changes, carbon sequestration and carbon stock in dry temperate forests of Chilas watershed, Gilgit-Baltistan
}

\author{
Avaliação das mudanças na cobertura do uso da terra, sequestro de carbono e \\ estoque de carbono em florestas temperadas secas da bacia hidrográfica de Chilas, \\ Gilgit-Baltistan
}

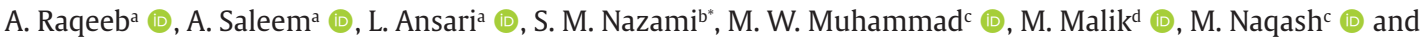 \\ F. Khalidc,e* (1D. \\ aPir Mehr Ali Shah Arid Agriculture University Rawalpindi Islamabad, Department of Forestry, Punjab, Pakistan \\ bUniversity of Haripur, Department of Forestry and Wildlife Management, Khyber Pakhtunkhwa, Pakistan \\ cPakistan Forest Institute Peshawar, Khyber Pakhtunkhwa, Pakistan \\ dUniversity of Peshawar, Department of Environmental Science, Peshawar, Khyber Pakhtunkhwa, Pakistan \\ ${ }^{e}$ GIS and Space Applications in Geosciences Lab (GSAG-L), National Center of GIS and Space Application (NCGSA), Institute of Space Technology, \\ Islamabad, Pakistan
}

\begin{abstract}
Land use and land cover change are affecting the global environment and ecosystems of the different biospheres. Monitoring, reporting and verification (MRV) of these changes is of utmost importance as they often results in several global environmental consequences such as land degradation, mass erosion, habitat deterioration as well as micro and macro climate of the regions. The advance technologies like remote sensing (RS) and geographical information system (GIS) are helpful in determining/ identifying these changes. In the current study area, changes in carbon stocks, notably in forest areas, are resulting in considerable dynamics of carbon stocks as a result of climate change and carbon sequestration. This study was carried out in the Diamer district of the Gilgit Baltistan (GB) Pakistan to investigate the change in cover change/land use change (particularly Forest Land use) as well as carbon sequestration potential of the forests in the district during almost last 25years. The land cover, temporal Landsat data (level 1, LIT) were downloaded from the USGS EROS (2016), for 1979-1989, 1990-2000 and 2001-2012. Change in land uses, particularly forest cover was investigated using GIS techniques. Forest inventory was carried out using random sampling techniques. A standard plot of size 0.1 ha $(n=80)$ was laid out to determine the tree density, volume, biomass and $\mathrm{C}$ stocks. Simulation of $\mathrm{C}$ stocks was accomplished by application of the $\mathrm{CO}_{2} \mathrm{FIX}$ model with the data input from inventory. Results showed a decrease in both forest and snow cover in the region from 1979-2012. Similarly decrease was seen in tree volume, tree Biomass, dynamics of C Stocks and decrease was in occur tree density respectively. It is recommended we need further more like project such as BTAP (Billion Tree Afforestation Project) and green Pakistan project to increase the forest cover, to control on land use change, protect forest ecosystem and to protect snow cover.
\end{abstract}

Keywords: land use cover changes, carbon sequestration, carbon stock, satellite data, simulation of carbon.

\section{Resumo}

O uso e as mudanças na cobertura da terra estão afetando o meio ambiente global e os ecossistemas das diferentes biosferas. O monitoramento, relatório e verificação (MRV) dessas mudanças são de extrema importância, pois muitas vezes resultam em várias consequências ambientais globais, como degradação da terra, erosão em massa, deterioração do hábitat, bem como micro e macroclima das regiões. As tecnologias avançadas, como sensoriamento remoto (RS) e sistema de informações geográficas (SIG), são úteis para determinar / identificar essas mudanças. Na área de estudo atual, as mudanças nos estoques de carbono, principalmente em áreas florestais, estão resultando em uma dinâmica considerável dos estoques de carbono como resultado das mudanças climáticas e do sequestro de carbono. Este estudo foi realizado no distrito de Diamer de Gilgit Baltistan (GB), Paquistão, para investigar a mudança na mudança de cobertura / mudança de uso da terra (particularmente uso de terras florestais), bem como o potencial de sequestro de carbono das florestas no distrito durante quase os últimos 25 anos. A cobertura da terra, os dados temporais do Landsat (nível 1, LIT), foram baixados do USGS EROS (2016), para 1979-1989, 1990-2000 e 2001-2012. Mudanças nos usos da terra, particularmente na cobertura florestal, foram investigadas

*e-mail: fkcbuneri@gmail.com; moazzam.nizami@uoh.edu.pk

Received: July 6, 2021 - Accepted: Sep. 15, 2021 
usando técnicas de SIG. O inventário florestal foi realizado por meio de técnicas de amostragem aleatória. Um lote padrão de 0,1 ha $(n=80)$ foi estabelecido para determinar a densidade das árvores, volume, biomassa e estoques de C. A simulação dos estoques de $\mathrm{C}$ foi realizada pela aplicação do modelo $\mathrm{CO}_{2}$ FIX com a entrada de dados do inventário. Os resultados mostraram uma diminuição na cobertura florestal e de neve na região de 1979 a 2012. Da mesma forma, diminuição foi observada no volume da árvore, biomassa das árvores, dinâmica dos estoques de $C$ e diminuição na densidade das árvores, respectivamente. É recomendado que precisemos de mais projetos como o BTAP (Billion Tree Afforestation Project) e o projeto Green Pakistan para aumentar a cobertura florestal, controlar as mudanças no uso da terra, proteger o ecossistema florestal e proteger a cobertura de neve.

Palavras-chave: mudanças no uso da terra, sequestro de carbono, estoque de carbono, dados de satélite, simulação de carbono.

\section{Introduction}

Forest cover is defined as the land covered by vegetation for more than 10 years (FAO, 2001). The vegetation cover of the earth is greatly affected by the anthropogenic activities during the last few decades (Fang et al., 2018). Such activities are having considerable effects not only on human health, but also of the resilience of the ecosystem which ultimately leading to climate change by certain processes (Lamichhane, 2008). These natural resources are not consumed and utilized with any sort of planning and scientific management (Prell et al., 2009). Forest management and conservation planning on scientific basis for their medicinal plant uses, management of rangelands, management of agricultural resources have utmost importance for fulfilling present needs and conservation for fulfilling future needs of human (Rizwan et al., 2015; Dhakal et al., 2019). Pakistan consists a diverse geography, which comprising a huge diversity of fauna and flora (Qureshi et al., 2011). Total forest cover of Pakistan is $5,832,506$ ha and other land cover classes have total area of $88,430,613$ ha. After ratifying the REDD+ by Pakistan in April 2011, many projects were carried out in the country to enhance carbon sequestration in the forests (Nizami, 2010).

C sequestration rates will decrease $4 \%$ in 2030 as compared to 2000 if land use remains unchanged. It is expected that in $2030 \mathrm{EU}$ terrestrial biosphere will sequester about $90-111 \mathrm{Tg} C$ annually which is about $6.5-8 \%$ of the current emissions by man (Muñoz-Rojas et al., 2011). To cope with reporting of the C stocks in Pakistan's different forest types, efforts were made national and provincial levels (Nizami, 2010; Nizami, 2012; Adnan et al., 2014; Alam and Nizami, 2014; Sajjad et al., 2016). No attempt has been made for $\mathrm{C}$ stocks simulation in any forest types of Gilgit Baltistan. And due to this pressure, forest cover is showing negative trend (Sundriyal and Sundriyal, 2004). Recently the study aimed at highlighting change in land use particularly for forest land use in the Diamer district of Gilgit Baltistan in Pakistan. This change in forest cover is associated both with social, environmental as well as economic factors (Phompila et al., 2017). Land use reflects the biophysical state of earth and subsurface of the earth (Briassoulis, 2009). Land use (LU) indicated man's activities as well as varied uses which are carried on over land and land cover (LC) refers to the natural vegetation, water bodies, rock/soil, artificial cover and others noticed on the land (Bisht and Kothyari, 2001; Gallant et al., 2004; Erb et al., 2007; Kumar and Pandey, 2013). Land use change (LUC) involves the nature and strength of change but it also includes spatial and temporal aspects (Verburg et al., 2004).
Land use and land cover change (LULCC) also carried out the modification of natural resources of the area, which may be direct or indirect modifications (Alqurashi and Kumar, 2014; Kleemann et al., 2017). Land use cover (LUC) is considered to be the most influential factor for change in carbon stocks on terrestrial ecosystems (Ozsahin et al., 2018). Mapping of land use cover changes, essential component drive different developmental and managerial index for land, water resources (Butt et al., 2015). The change in land cover can be determined through satellite pictures and aerial images (Yang and Lo, 2002). For this purpose land cover maps are used by the managers as well as scientists to understand the current landscape (Groot et al., 2010). RS (Remote sensing) and GIS (geographic information system) are important tools in acquiring timely and accurate spatial data of LULC, and also assessing the changes in a study area (Reis, 2008; Srivastava et al., 2013; Pervez et al., 2016; Yasir et al., 2020). Hence RS is commonly used to detect and track land use at various scales (Olokeogun et al., 2014; Rai et al., 2016; Mishra et al., 2016; Hua, 2017).

There are different organizations involved in GIS/RS to assess natural resources and particularly forest resource of the country. The recent studies carried out through satellite images and validation by experts to form sub district level forest statistic for Western Himalaya pointed out that $0.38 \%$ area has been degraded/deforested during the last two decades (Qamer et al., 2016). There is no accurate and reliable forestry baseline data are available. Therefore the objectives of study are to assess the land use cover changes in dry temperate forests of Chilas watershed using GIS and RS. To assess carbon stocks in dry temperate forest ecosystem of Chilas watershed and to determine the potential of carbon sequestration of the dominant tree species for the next 100 years.

\section{Materials and Methods}

\subsection{Study area}

This research were carried out in Chilas district of the Gilgit Baltistan (GB) Pakistan. Geographically, it is situated at $3502^{\prime}$ and 35 50' $\mathrm{N}$ and 730 6' and 740 44' $\mathrm{E}$ (Figure 1). It covers an area of $72,496 \mathrm{sq}$. $\mathrm{km}$. The entire area falls within the high mountainous ranges of Karakoram, Himalayas, Hindukush and Pamir with most of the area situated at or above $4500 \mathrm{~m}$ (Ali and Benjaminsen, 2004). Below 3000m, precipitation is very low, rarely exceeds from $200 \mathrm{~mm}$ per annum. However, there is strong altitudinal gradient, and at 


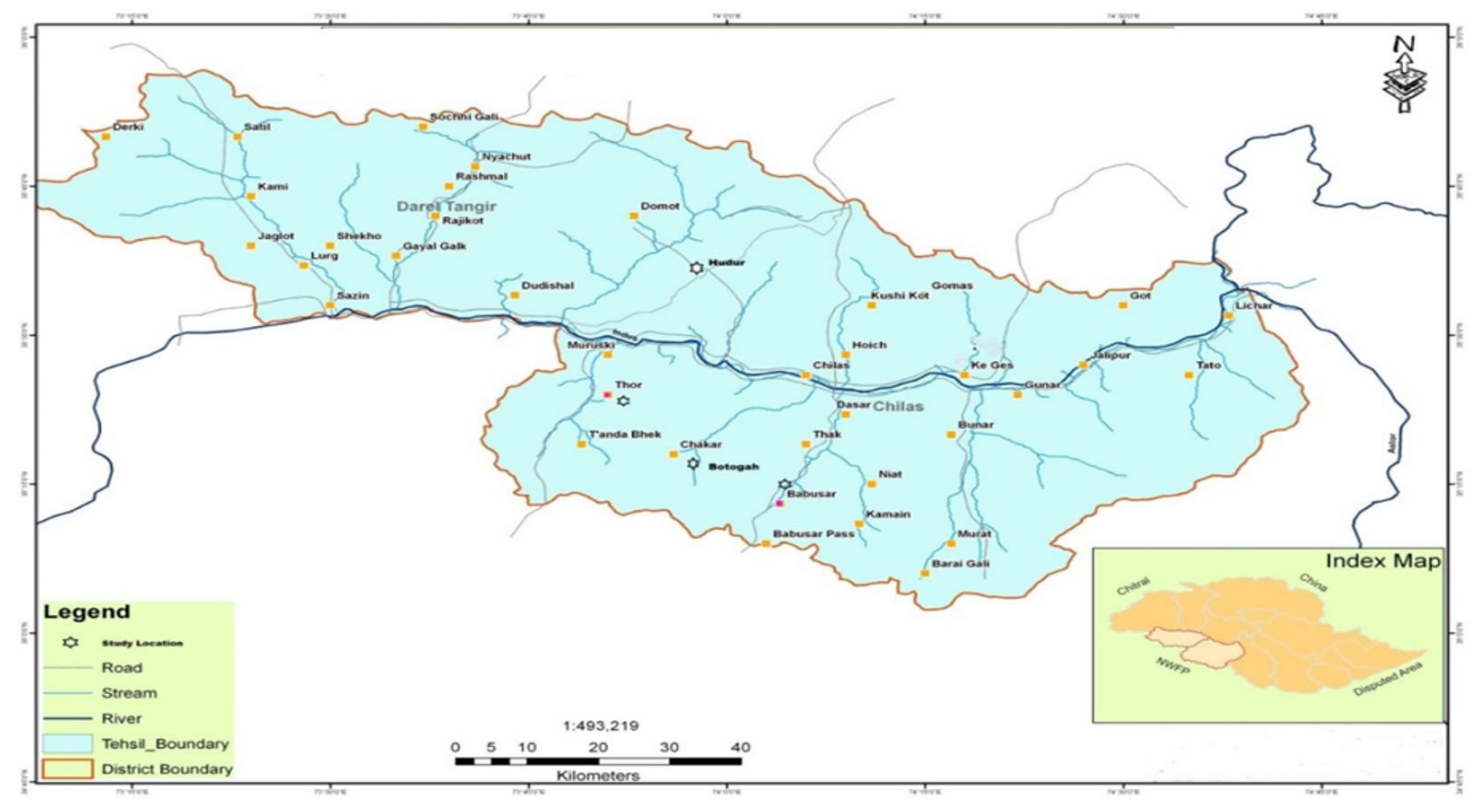

Figure 1. Distribution of sites in the study area.

$6000 \mathrm{~m}$ altitude, $2000 \mathrm{~mm}$ snow falls annually. Temperature also vary from $40^{\circ} \mathrm{C}$ in valley bottoms in summer to less than $-10^{\circ} \mathrm{C}$ in winter (GOP, 1991; IUCN, 2002). Major forest tree species of the study area includes Pinus gerardiana (Chilgosa), Cedrus deodara (deodar), Picea smithiana (Spruce), Pinus wallichina (kail), Abies pindrow (Iqbal 1982, 2001; Ali and Benjaminsen, 2004; Abdul et al., 2014).

\subsubsection{To assess the land use cover changes in dry} temperate forests of Chilas watershed using GIS and Rs.

For interpretation of land cover, temporal land sat data (level 1, LIT) was downloaded from USGS EROS (2016), for 1989, 2000 and 2012. Normally for attaining the optical satellite data in Gilgit Baltistan (Northern area of Pakistan), the most suitable time is August to October because during time least snow and cloud cover is present. The data obtained from Landsat satellite is a reliable appropriate resolution data source and is very useful to quantify land cover changes reasonably over longer periods of time (Sleeter et al., 2013). The administrative boundaries of the district and sub districts were double checked via GOP (1991), to assess the change in land use from 1979 to 2012.

\subsubsection{Satellite data}

Thematic maps (land use) of the study area for the years 1979-89, 1990-2000 and 2012 were prepared and used to gauge the changes occurred during this time in land use and land cover. The software ARGIS 10.2 and ERDAS 10.1 was utilized for data processing. The existing land cover maps were developed by processing data on ArcGIS 10.2. Image mosaic, geo-referencing and sub setting was carried out through ERDAS Imagine 10.1 software. All the raw data for all land uses in study area were obtained by using Landsat images of 30 meter resolution.

\subsubsection{Topographic maps}

The topographic maps show all the details of the features that appear ground surface. The corresponding symbols and features on map were shown by map legend or key. These maps show coordinate grid and geographic gradient which determine accurate and clear position of features that are mapped (Nelson and Geoghegan, 2002).

\subsubsection{ISO data clustering}

The data collected from topographic maps were merged with ISO data. This ISO data method was developed by Hall, Ball and others in 1960. This method adds the division of clusters and processing of fusion of clusters (Arai and $\mathrm{Bu}$, 2007). An area with same characteristics is labelled as land use form i.e. Grassland, Forest, build up areas, Agriculture, water depths. The clustering method assumes that the pixels have same spectrum. In data clustering unsupervised classification was used. In spectral classification the image is classified on different natural grouping of spectral grids of pixels. Having same properties, the pixels were assigned to same class because the pixels have same properties for each class (Nelson and Geoghegan, 2002).

\subsubsection{Land use and land cover changes analysis}

Analyses of remote images carried after confirming the ground trothing, a method already adopted by Chakraborty et al. (2001). Points were marked using GPS which were correspondent with certain land uses and land cover forms. The identified landforms include forest, irrigated agriculture, rain fed agriculture, woodlands, shrub lands, water bodies and sisal plantations. It was recommended by Johnson and Sharpe (1983) that using data sets of at least two time-period for detection of changes in land cover and land use. The Landsat images for the years 1987, 2001 
and 2011 respectively in the study areas were analyzed. One was Thematic Mapper, while 2 others were Enhanced Thematic Mapper plus. GLOVIS, was the source for these remote maps. The Maps for the 1987 and 2011 were from the month of February and that of 2011 map was for March. But given periods of downscaled / map and images coincide with the dry season so uncertainties may be minimized.

\subsubsection{Image classification}

Using satellite images by spectral classes for different land uses were put in one clusters and classes were assigned to pixels. ENVI 4.7 software was used for Multi-temporal Landsat data processing (ESRI, 2009). We defined Regions of Interest (ROI) for extraction of statistics for assigning classes. We used Supervised classification with false (4, 3 , and 2) color composite bands for clustering pixels in one set of data into different classes which were corresponding to the certain ROI. To classify the images, Mahalanobis distance methods were adopted (ESRI, 2009). According to Basavarajappa et al. (2015) guidelines, overall 7 land use and land cover types were classified. These are forests, rain fed agriculture, irrigated agriculture, scrub forest, dense forests, water bodies and saal artificial plantations.

\subsubsection{Change detection}

Dynamics in land use and land cover types which were classified was also detected. For this purpose, the well-known software ENVI EX (ESRI, 2009) was used and thematic change detection was carried out by the comparison of the two images which were collected for the time periods (1979-89, 1990-2000 and 2001-2012 images).

\subsection{To assess carbon stocks in dry temperate forest ecosystem of Chilas watershed}

Ground trothing was also followed in the study area to analyze the $\mathrm{C}$ stocks in the forests.

\subsubsection{Plot selection}

Primary data for forest past history was collected. Forest maps and information regarding growing stocks was also collected. In order to carry out forest inventory four sites namely (Thore, Botogah, Hudur and Babusar) in the study area were selected randomly as true representative of the forest ecosystem of the area. In each site 20 plots were laid out randomly. Distribution of sites is given in Figure 1.

\subsubsection{Plot size}

For all the plots a standard size of one hectare was adopted. The shape of the plots was with radius of $56 \mathrm{~m}$ a hectare circular for upper strata of the forest and a sub plot of $1 / 10^{\text {th }}$ of hectare for under strata of the forest (within $56 \mathrm{~m}$ radial plot). On the basis of the area, no. of plots and size of grids were calculated for on ground movements.

\subsubsection{On plot measurements}

Following stand characteristics were investigated in each plot on all the sites. Diameter of all trees at breast height which comes in the (56 m circular) plot were measured. Over all, the five dominant trees ( $\mathrm{m}$ ) of all diameter classes were taken for height measurement. Using Abney`s level and geometric formulae. Destructive sampling of under strata was carried out through establishing $9 \mathrm{~m}$ radius plot with in the $56 \mathrm{~m}$ radial plot (considering the centre). All the under strata vegetation was weighed $(\mathrm{Kg})$ by bringing them to laboratory. The oven dried weight was considered.

\subsubsection{Soil sampling}

From the two depths of different soil (0-15 and 15-30 $\mathrm{cm})$ soil samples was chosen. These were in R3 pattern (three replications) within in each plot and soil core sampler was used for collecting soil sample. Weight of each sample was calculated in the field and then these samples were stored for further laboratory analysis in labelled bags. For determining soil bulk density of study sites soil core sampler of known volume was used. The volume of core sampler was $0.007854 \mathrm{~m}^{3}$. Soil bulk density was calculated as Equation 1:

$$
\text { Soil Bulk density }\left(\mathrm{gm} / \mathrm{cm}^{3}\right)=\text { Soil weight }(\mathrm{gm}) \div \text { volume of cylinder }\left(\mathrm{cm}^{3}\right)
$$

\subsection{Data analysis}

\subsubsection{Analysis of biomass}

The measurement of biomass is considered as the most reliable method for calculation of the tree carbon stocks. In order to get the biomass, first volume over bark (VOB ha-1) of trees was calculated and later biomass was determined using prescribed methodology (Lugo and Brown, 1992; Gillespie et al., 2008; Brown et al., 1989).

\subsubsection{Volume calculations}

The standard methodology was followed to determine the volume $\left(\mathrm{m}^{3} \mathrm{ha}^{-1}\right)$ for all sites which were sampled and for this formula generated by Philip (1994) was followed, and then multiplied the volume by wood density i.e. $\mathrm{kg} \mathrm{m}^{-3}$ of particular species to have total biomass $\left(\mathrm{kg} \mathrm{ha}^{-1}\right)$. The wood density of each species is given in Table 1 (Equation 2).

$$
\text { Volume of tree }\left(m^{3}\right)=(\pi / 4) \times d 2 \times h \times f
$$

\section{Where}

$\mathrm{H}=$ tree height; $\mathrm{d}^{2}=$ Square of diameter; $\mathrm{f}=$ Form factor Here " $\pi$ " is equal to 3.14 , " $d$ " is equal to diameter at breast height " $h$ " is the tree height in meters and " $\mathrm{f}$ " is the form factor of the species. Height was measured of the 5 dominant trees from each diameter class and after that, average height $(\mathrm{m})$ for each dia class was taken for volume calculation.

\subsubsection{Stem wood biomass calculations}

The total stem biomass ( $\mathrm{kg}$ ) was measured with the help of wood density $\left(\mathrm{Kg} \mathrm{m}^{-3}\right)$ and volume of the stem $\left(\mathrm{m}^{3}\right)$. For the present study wood density values were taken from the past research papers and technical reports. The values are reported in Table 1 (Equation 3).

$$
\text { Biomass }(\mathrm{kg})=\text { Volume }\left(\mathrm{m}^{3}\right) \times \text { Wood Density }\left(\mathrm{kg} \mathrm{m}^{-3}\right)
$$




\subsubsection{Branch, leaves and roots biomass (BLRB) calculations}

Biomass allometric models are usually used for estimating the biomass of the tree species Wani and Qaisar (2014). Allometric models as well as biomass expansion factors of the dominant tree, a literature review of the research area's species was attempted. All details of the contribution of each tree component in total biomass of the tree are given in Table 2 (Equation 4).

Carbon Conc. $=(B)$ Blank titration $-(S)$ Actual titration $\times 12 \times M(F e(N H 4) 2(S O 4)$

Weight of oven dried soil in gm x 4000

Where:

$\mathrm{B}=\mathrm{mL}$ of $\left(\mathrm{Fe}\left(\mathrm{NH}_{4}\right)_{2}\left(\mathrm{SO}_{4}\right)\right.$ solution used to titrate blank $\mathrm{S}=\mathrm{mL}$ of $\left(\mathrm{Fe}\left(\mathrm{NH}_{4}\right)_{2}\left(\mathrm{SO}_{4}\right)\right.$ solution used to titrate sample

$12 / 4000=$ mill equivalent weight of $\mathrm{C}$ in $\mathrm{g}$.

The oxidisable organic $\mathrm{C}$ was converted to total $\mathrm{C}$ by multiply with 1.30 correction factor given by Walkley and Black. The Bulk density $\left(\mathrm{gm} \mathrm{cm}^{-3}\right)$ was also calculated and used to estimate total carbon stocks $\left(\mathrm{t} \mathrm{ha}^{-1}\right)$ in soils of these forests.

\subsubsection{Biomass of under strata of forest}

In the present study all the vegetation in under strata within circular plot of $9 \mathrm{~m}$ radius was destructively sampled. All the destructively sampled material was placed in the labelled bags to bring them in the laboratory. Oven dried weights were determined with accuracy of $0.01 \mathrm{~kg}$. The drying was carried out in oven at $72^{\circ} \mathrm{C}$ for 48 hours. Biomass were calculated species wise by using the following formula (Equation 5):

Biomass $(\mathrm{Kg})=$ dry weight $(\mathrm{kg})$

\subsubsection{Soil analysis}

The $\mathrm{C}$ stocks in the soil of the forest were determined from the analysis of the soil samples. For determining the carbon concentration in the soil, the method of oxidisable organic carbon given by Walkley and Black (1934) outlined in (Allison, 1965); (Rayment and Higginson, 1992; Anderson and Ingram, 1993) was used because of available resources.

\subsection{Total carbon stocks}

\subsubsection{Total C stocks in upper strata vegetation}

The total biomass in the understory vegetation was determined by calculating the total weight of the understory vegetation in $\mathrm{kg} \mathrm{ha}^{-1}$. Later the total carbon stock in upper strata vegetation of the forests was determined by multiplication of the total plant biomass by convertible factor which is representative of the average carbon content in plant biomass. This e factor $(0.50)$ general represents that $50 \%$ of total plant biomass is equal to C (Roy et al., 2001; Malhi et al., 1999) has already used this factor and it is standard procedure of measuring $C$ stocks in the vegetation under story.

\subsubsection{Total $C$ stocks in under strata vegetation}

To determine and calculation of the carbon stock in under strata vegetation were determined by multiplying the total weight (oven dried $\mathrm{kg} \mathrm{ha}^{-1}$ ) with 0.50 conversion factor (Roy et al., 2001; Brown and Lugo, 1982; Malhi et al., 1999).

\subsubsection{Total carbon stocks in forest soils (TOC)}

The Toc was calculated to have a clear picture of $C$ stocks in three levels (upper and under strata vegetation

Table 1. Wood density $\left(\mathrm{Kg} \mathrm{m}^{-3}\right)$ of all the dominant species of study area.

\begin{tabular}{cccc}
\hline S. No & Species & Wood Density $\left(\mathbf{k g ~ m}^{\mathbf{3}}\right)$ & References \\
\hline 1 & Cedrus deodara (Roxb.Ex lamb) G.Don & 460 & Wani and Qaisar (2014) \\
2 & Pinus wallichiana A.B.Jackon & 430 & Anwar (2015a) \\
3 & Pinus gerardiana Wall.Ex Lamb. & 500 & Anwar (2015a) \\
4 & Abies pindrow Royle & 420 & Haripriya (2000) \\
5 & Picea smithiana (Wall) Boiss & 430 & Anwar (2015a) \\
\hline
\end{tabular}

Table 2. Contribution of each tree component in total tree biomass (Kg).

\begin{tabular}{|c|c|c|c|c|c|c|}
\hline \multirow{2}{*}{ S. No } & \multirow{2}{*}{ Species } & \multicolumn{3}{|c|}{ Biomass (kg) of each component } & \multicolumn{2}{|c|}{ Total Biomass } \\
\hline & & Stem & Branch & Leaves & Twigs & Root \\
\hline 1 & Cedrus deodara (Roxb.Ex lamb) G.Don & 226.67 & 64.14 & 18.19 & 77.25 & 386.25 \\
\hline 2 & Pinus wallichiana A. B. Jackon & 192.0 & 81.7 & 37.9 & 62.32 & 200.92 \\
\hline 3 & Pinus gerardiana Wall.Ex Lamb & 230 & 194 & 38 & 65.12 & 527.12 \\
\hline 4 & Abies pindrow Royle & 1706.32 & 304.54 & 67.6 & 56.07 & 426.90 \\
\hline 5 & Picea smithiana (Wall) Boiss & 1740.40 & 309.24 & 65.38 & 56.78 & 456.08 \\
\hline
\end{tabular}


and soils). To get this information the total carbon that has been sequestered forests soils was sampled and bulk density bulk density at varying ( $0-15$ and $15-30 \mathrm{~cm})$ depths in each forest site was also calculated. The combinations of bulk density and the $C$ concentration provided the answer for the analysis of the $\mathrm{C}$ stocks in the soil.

\subsubsection{Total carbon stocks in the forest ecosystem}

$\mathrm{C}$ stocks in an ecosystem is normally determined by various methods including remote sensing data, ground trothing, field inventory and flux towers. However, on large scales comparisons of fluxes are also made to determine the dynamics in C stocks in different ecosystems (IPCC, 2003). Different micrometeorological techniques including eddy covariance are being used for determining the fluxes. Remote sensing data collected by RS/GIS and toposheets is also used to obtain such type of data.

In this study the inventory based carbon budget assessment has been demonstrated. The $\mathrm{C}$ stocks in the upper and under "strata" vegetation of the forest as well as in the soil have also been determined to present the $C$ stock of the entire forest ecosystem.

\subsection{To determine the potential of carbon sequestration of the dominant tree species for the next 100 years}

The simulation of the $C$ stocks for next 100 years was carried out for each dominant species in the study area. The assumption was made that in the forest land use the same species will prevail for the next 100 years. For simulation purpose the $\mathrm{CO}_{2}$ FIX Model version 3.2 was used. This model has been prepared by Prof. Morgen of the Wageningen University Netherland.

\subsubsection{The $\mathrm{CO}_{2}$ FIX model}

The $\mathrm{CO}_{2}$ FIX V3.2 is stand level simulation model which determines the $\mathrm{C}$ stocks and fluxes in the forest ecosystem utilizing the determining dynamics of $\mathrm{C}$ stock per unit time (Schelhaas et al., 2004). The physically stored total $\mathrm{C}$ stock in an ecosystem at (CTt; $\mathrm{Mg} \mathrm{C} \mathrm{ha-1)}$ is described as in Equation 6.

$C T t=\sum$ Cbit

Where Cbt is the total carbon stored in living (above strata as well as below strata vegetation) biomass at any time ' $\mathrm{t}$ ' ( $\left.\mathrm{Mg} \mathrm{ha}^{-1}\right)$ and Cst is the carbon stored in soil organic matter $\left(\mathrm{Mg} \mathrm{ha}^{-1}\right)$.

\subsubsection{Carbon stored in living biomass}

$\mathrm{C}$ stored in living biomass are simulated in Biomass module of the $\mathrm{CO}_{2}$ Fix by Equation 7 and 8. This module calculated $\mathrm{C}$ stocks per unit area of the living biomass, as influenced by the stem growth for (including bark), leaves, branches plus sub branches, roots, and the mortality of the vegetation and harvesting. The growth of all the tree components other than stem is determined by the coefficient of the relative growth compared with the growth of the stem biomass. The carbon stored in living biomass
(Cbt) of the entire forest ecosystem, can be expressed as the sum of the biomass of each tree component.

$$
C b t \sim X C b i t
$$

Where C stocks exhibit by living biomass of cohort 'i' at time't' (MgC ha-1) is expressed as Cbitis.

$$
\text { Cbitz } 1 \sim \text { CbitzKc } 1 / 2 \text { Gbit }\{\text { Msit }\{\text { Tit }\{\text { Hit }\{\text { Mlit }
$$

Where "Cbit" can be calculated in equilibrium in between the original biomass, Gbit designates biomass growth, $\mathrm{T}$ it is the turnover of branches, foliage and roots, Msit is tree mortality due to senescence, Hit is the harvest and Mlit is mortality due to harvesting and Kc is a co efficient used for converting biomass to carbon content ( $\mathrm{Mg} \mathrm{C}$ per Mg biomass dry weight).

\subsubsection{Carbon stored in soil organic matter}

The total $\mathrm{C}$ stocks in the soil can be determined via inbuilt YASSO module in the $\mathrm{CO}_{2}$ FIX model. The module takes Soil $\mathrm{C}$ input directly from biomass module. This module takes three residual portions and five decomposing parts from the biomass module. To calculate the dynamics of $C$ stocks in the soil under each tree species, simulation were carried out separately for each species by running Yasso module separately.

\subsection{Model parameters}

\subsubsection{Species characteristics}

The Table 3 showing the characteristics of the species that has been utilized for calculation of simulation of $\mathrm{C}$ stocks through $\mathrm{CO}_{2} \mathrm{FIX}$. The stem volume growth and contribution of each tree component are the basic parameters which are taken into consideration while simulating the $C$ stocks by the model. Then extrapolations for the entire 1 ha. Plot is carried out by considering the tree density (No. of Trees ha ${ }^{-1}$ ). Mortality, harvest and turnover on one hands and increased in C Stocks in the living biomass on other hands gives total $C$ stocks in the model. Input for the soil module includes turnover and mortality and harvesting processes.

\subsubsection{Biomass module}

The current annual increment (CAI) of the stem wood volume $\left(\mathrm{m}^{3} \mathrm{ha}^{-1} \mathrm{yr}^{-1}\right)$, biomass turnover rate, initial biomass, growth and mortality of each functional group relative to standing biomass, and interactions within and between the functional group are the main input for the biomass module. Entire inventory of the forest ecosystem carried out to get information about the diameter at breast height (bdh), height (for calculating total productivity (Volume ha- ${ }^{1}$ ) and CAI), living biomass growth and mortality of trees. The turnover rates for branches, foliage and roots were gathered from Iqbal 2001. Wood density (dry) of Abies pindrow (fir), Picea smithiana (Spruce), Cedrus deodara (deodar), Pinus gerardiana (Chilghosa) and Pinus wallichina (Kail) were pooled from (Anwar, 2015a)(Table 3). Comparison of dbh and height of the trees at a particular 
Table 3. Species characteristics for $\mathrm{C}$ simulation through $\mathrm{CO}_{2}$ FIX model.

\begin{tabular}{ccccc}
\hline S. No & Species & $\begin{array}{c}\text { Range of DBH } \\
(\mathbf{c m})\end{array}$ & $\begin{array}{c}\text { Range of CAI } \\
\left(\mathbf{m}^{\mathbf{3}} \mathbf{h a}^{-\mathbf{1}} \mathbf{\mathbf { y r } ^ { - 1 }}\right)\end{array}$ & $\begin{array}{c}\text { Tree Density } \\
(\mathbf{N o .} \text { of trees/ha) }\end{array}$ \\
\hline 1 & Cedrus deodara (Roxb. Ex Lamb) G. Don & $8-123$ & $0.001-0.824$ & 9.11 \\
2 & Pinus wallichiana A. B. Jackson & $8-110$ & $0.001-0.868$ & 8.67 \\
3 & Pinus gerardiana (Wall. Ex Lamb) & $8-65$ & $0.002-0.320$ & 3.17 \\
4 & Abies pindrow Royle & $6.5-100$ & $0.003-1.642$ & 7.94 \\
5 & Picea smithiana (Wall) Boiss & $9-118$ & $0.595-3.386$ & 3.8 \\
\hline
\end{tabular}

age represented promising results with (Anwar, 2015b; Abdul et al., 2014). The volume calculations were based on diameter and height parameters (Philip, 1994).

The main reason for comparing with the (Anwar, 2015a; Abdul et al., 2014) the ground truths taken from the sample plots, while the growth and yield tables were not considered as they are often made in fully stocked stands and the natural forest have no specific spacing. Allometric equations were used for calculating the biomass of all the tree components (including branches, foliage and stems) in this study. While calculating the stem biomass using basic wood density of the dominant tree species Abies pindrow (Fir), Picea smithiana (Spruce), Cedrus deodara deodar), Pinus gerardiana (Chilghosa) and Pinus wallichina (Kail) the result were closely resembling the calculations of (Anwar, 2015b; Abdul et al., 2014) models, so in the present research and their models were adopted for estimating branches, foliage and roots biomass.

\subsubsection{Soil Module}

To full fill the requirement of data for determining soil C stocks, the soil module required information of litter input $\left(\mathrm{MgC} \mathrm{ha}^{-1} \mathrm{yr}^{-1}\right.$ ) from decomposition of foliage, fine roots, branches, stem and coarse root. The calculated turnover rates, natural mortality, management mortality, and harvest wastes is also required by the simulator in other modules of the model. The other main input for this module is temperature and rainfall data of the region which later calculates potential evapotranspiration rate for the region. This is also important for highlighting the rate of decomposition of leaf as well as root litter. The size of non-woody litter, finer and coarse litter pools was finding from diverse by inputs source of litter, minus the fractionation rate per pool. The proportion allocated to soluble compounds, holocellulose, and lignin-like compounds is in turn finding by fractionation rates, litter quality classes (Schelhaas et al., 2004). In baseline situation for simulation in the current study is shown in Table 3.

\section{Results and Discussion}

3.1. To assess the land use cover changes in dry temperate forests of Chilas watershed using GIS and RS.

The dynamics of all six land use/land cover changes are separating into different sorts, such as snow covered land; bare soils, forest land, bush/grassland, agricultural land and water bodies during the year 1979-89, 1989 to 2000 and 2000-2012. In the research work, the image-processing approach was found to be effective in producing compatible LULC data over time, irrespective of the differences in spatial, spectral and radiometric resolution of the satellite data. According to the produced LULC map for the year 1979 to 1989 (Figure 2), Snow-covered land, bare soil and forest land were determined are dominant LULC in the area, while other land uses were bush/grassland, agriculture and water, whereas they were bare soil and forest for the year 1989 (Figure 3). The LULC map of 2012 illustrates that the predominant types of (LULC) classes were grasslands, bare soils and forests land (Figure 4).

The land use/land cover changes were detected using geospatial techniques as shown in Figure 2, 3 and also listed in Table 4. The study revealed that for the year 1989 to 2000 , the agricultural area has increased by 0.569 (ha) which was 2.279 ha in 1989 and 2.848 ha in 2000 . The forests have decreased its area from 106.589 ha in 1989 and 100.557 (ha) in 2000 the decreased area was 6.032(ha). Grass/Bushes lands were increased which was 21.247 ha in 2000. The snow showed a huge decreased area of about 49.248(ha) during 1989 to 2000 . The soil has increased by an area of 48.916(ha) which was 819.96 (ha) in1989 and 196.88 (ha) in 2000. The water decrease 0.001 (ha) area of about 1.179(ha) 1989 and 1.178(ha) in 2000.It was revealed that agricultural area showed an increase with the time (Table 4, 5 and Figure 2, 3).

The total increase in agricultural land use was $20.21 \%$ from 1989 to 2000 and then it showed increasing trend up to $42.62 \%$ increase till 2012 . An increase in agricultural land use from 1990 to 2012 is also mentioned by (Qamer et al., 2016). The forest land use showed markedly decreasing trend from 1989 to 2012 i.e $5.56 \%$ in 1999 and up to $47.15 \%$ in 2012 may be due to deforestation in the area. Ali et al., 2010) mentioned that decreased in forest cover occurred in the region due to infrastructural development especially roads. The grass /bushes land use also increased from 1989 to 1999 up to $26 \%$ but later from 2000 an exponential increased was determine in the grass land use. Qamer et al., 2016 identified that $8 \%$ increase in grass land use using temporal land set data taken from USGS EROS (2016). The snow covered land also decreased by $33.19 \%$ from 1989 to 1999 and then 62.16\% up to year 2012. Qamer et al., 2016 also mentioned that snow cover land use decreased up to $5 \%$ in area from 1990 to 2012 . The natural water bodies showed decrease in an area up to $0.08 \%$ from the year 

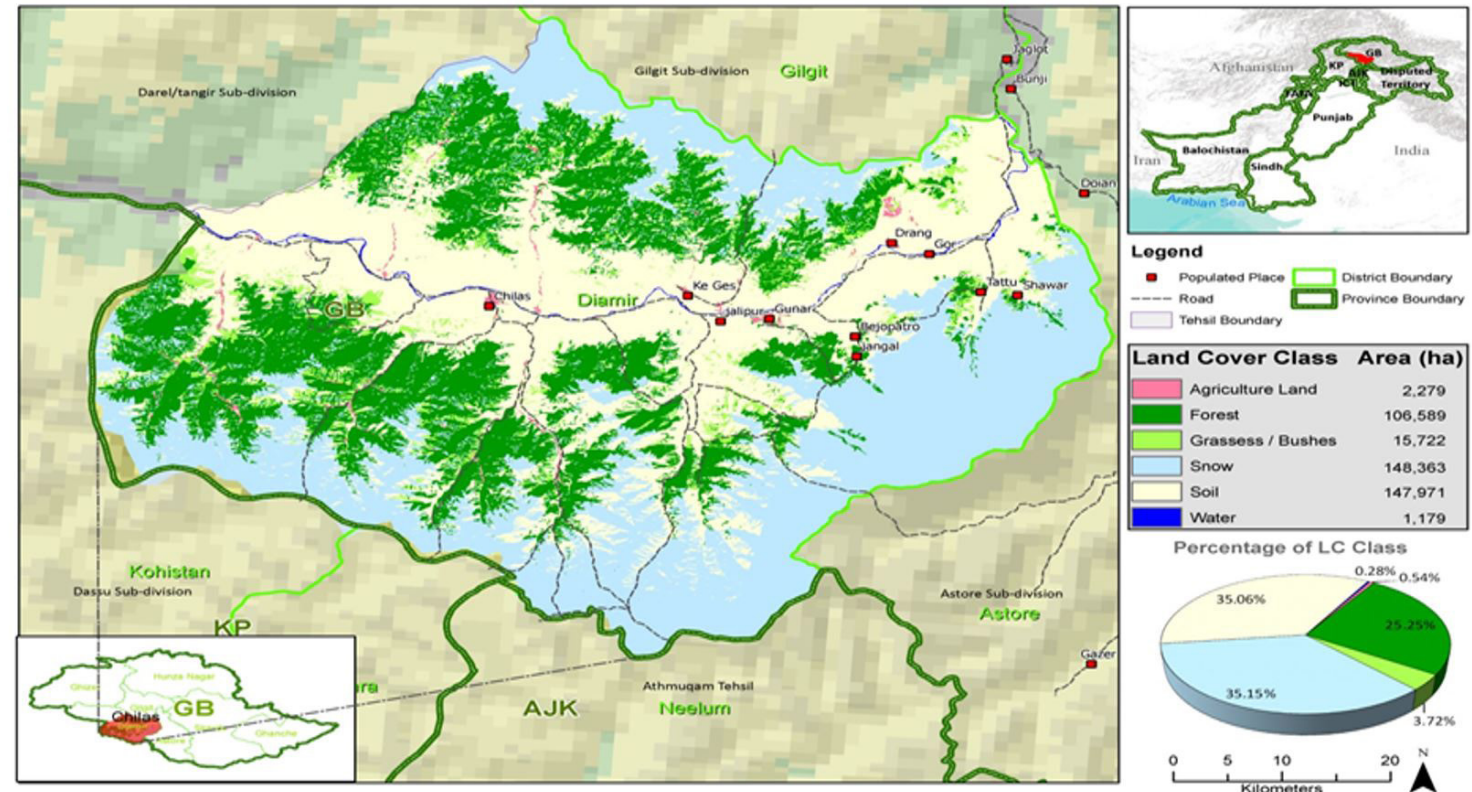

Percentage of LC Class

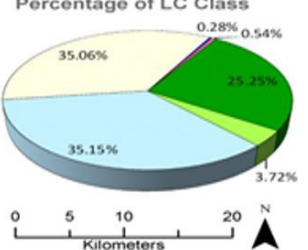

Figure 2. Land use/land cover map for year 1979 -89.
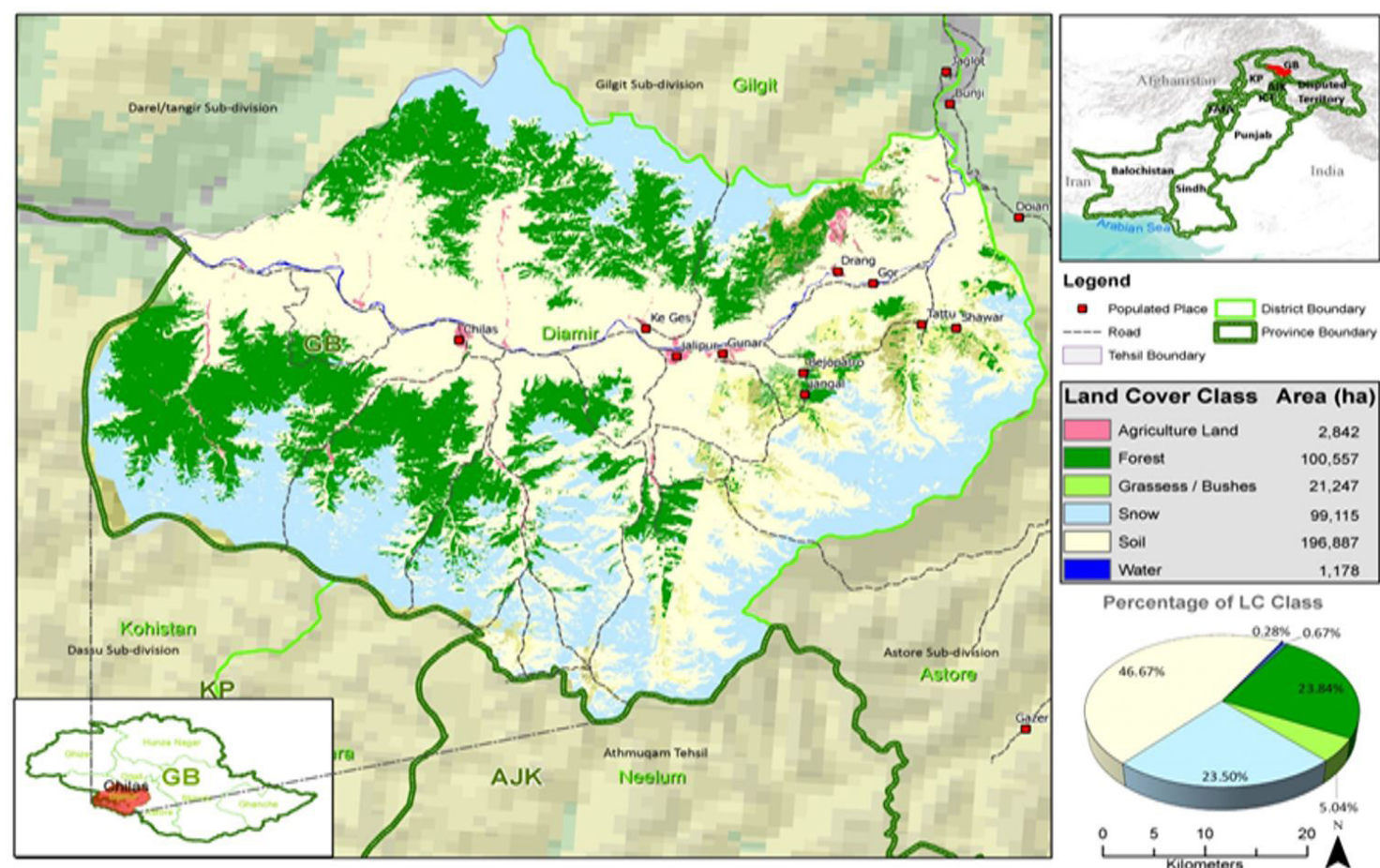

Percentage of LC Class

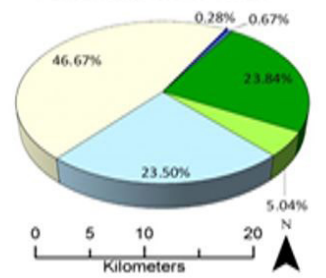

Figure 3. Land use/land cover map for year 1990-2000.

1989 to 1999 while $99.15 \%$ increase was determined from 2000 to 2012. The reason may be melting of the snow resulted in enhanced wet lands in the area. Gautam et al. (2003), Soini, (2005), Lunetta et al. (2006), Yu et al. (2011), Hu et al. (2019), and Schädler et al. (2019) also revealed that the change in land use cover change is not uniform in the region as the area consists of diverse ecosystems.
3.2. To asses carbon stocks in dry temperate forest ecosystem of Chilas watershed

\subsubsection{Species composition and tree density}

The inventory of forest in the study area revealed that following tree species are dominating in this forest 

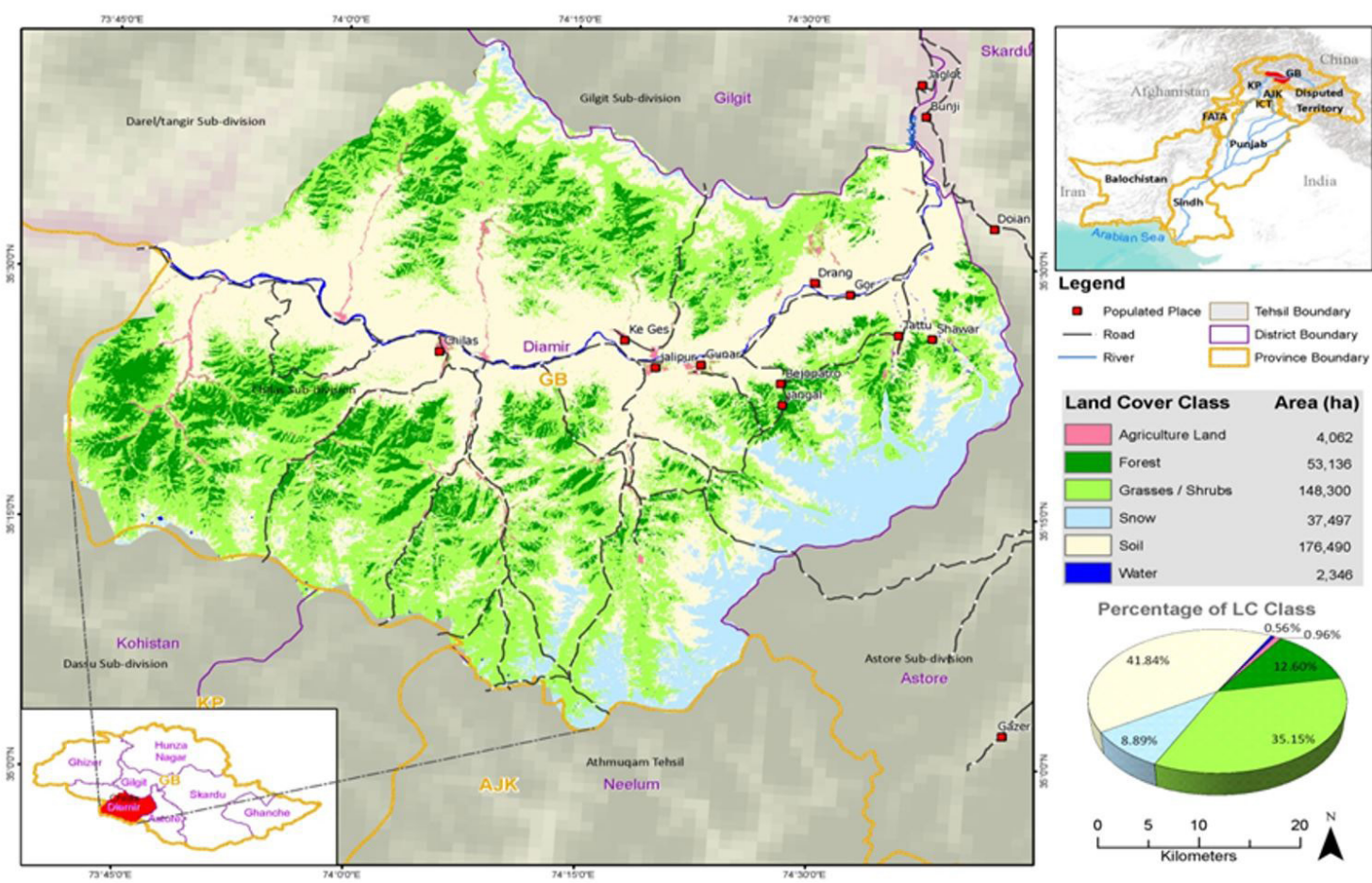

Figure 4. Land use/ Land cover map for year 1999-2012.

Table 4. Land use changes by area occurred during 1989 to 2000.

\begin{tabular}{cccc}
\hline & $\mathbf{1 9 8 9}(\mathbf{h a})$ & $\mathbf{2 0 0 0}(\mathbf{h a})$ & Difference (ha) \\
\hline Agriculture & 2.279 & 2.848 & +0.569 \\
Forest & 106.589 & 100.55 & -6.032 \\
Grass/Bushes & 15.722 & 21.247 & +5.522 \\
Snow & 148.363 & 99.115 & -49.248 \\
Soil & 147.971 & 196.887 & +48.916 \\
Water & 1.179 & 1.178 & -0.001 \\
\hline
\end{tabular}

Table 5. Land use changes by area occurred during 2000 to 2012.

\begin{tabular}{cccc}
\hline & $\mathbf{2 0 0 0}(\mathbf{h a})$ & $\mathbf{2 0 1 2}$ (ha) & Difference (ha) \\
\hline Agriculture & 2.848 & 4.062 & +1.214 \\
Forest & 100.55 & 53.137 & -47.421 \\
Grass/Bushes & 21.247 & 148.300 & +127.053 \\
Snow & 99.115 & 37.497 & -61.618 \\
Soil & 196.887 & 176.490 & -20.397 \\
Water & 1.178 & 2.346 & +1.167 \\
\hline
\end{tabular}

ecosystem: Abies pinbrow (Fir), Picea smithiana (spruce), Cedrus deodara (deodar), Pinus gerardiana (Chilghosa Pine) and Pinus wallichina (Kail). These tree species have also been documented as dominant species of the dry temperate forest ecosystem of Himalaya Mountain (Abdul et al., 2014; Champion et al., 1965). From the secondary data it was pointed out the mean tree density (including all species) was 78 trees ha ${ }^{-1}$ during the year 1979 to 89 comprising 20 , $16,16,7.0$ and 19 tree ha $^{-1}$ respectively for Abies pinbrow (Fir), Picea smithiana (spruce), Cedrus deodara (deodar), Pinus gerardiana (Chilghosa Pine) and Pinus wallichina (Kail) (Iqbal, 1982). While the mean tree density ha ${ }^{-1}$ 
during the year 1990 to 1999 was 50 comprised of 13 , 7, 12, 5.00, and 13 respectively for Abies pinbrow (Fir), Picea smithiana (spruce), Cedrus deodara (deodar), Pinus gerardiana (Chilghosa Pine) and Pinus wallichina (Kail) (Iqbal, 2001). The ground inventory carried out in this study revealed that the mean tree density ha ${ }^{-1}$ for the year 2012 was 33 comprised of 8, 4, 9, 3 and 9 respectively for Abies pinbrow Fir), Picea smithiana (spruce), Cedrus deodara (deodar), Pinus gerardiana (Chilghosa Pine) and Pinus wallichina (Kail) (Figure 5). The results of the present study was consistent with the study of Abdul et al. (2014) mentioned tree density of 15,2 and 4 trees ha $^{-1}$ for kail, deodar, Fir and Chilgosa in the Diamer district in the study area in 2010.

\subsubsection{Tree volume}

The mean tree volume determined from the secondary data for the year 1979 -89 and 1990-99 was $129.61 \mathrm{~m}^{3}$ ha $^{-1}$ in which Abies pinbrow Fir), Picea smithiana (spruce), Cedrus deodara (deodar), Pinus gerardiana (Chilghosa Pine) and Pinus wallichina (Kail) contributed 48.85, 33.2, 9.11, 3.9 and $34.55 \mathrm{~m} 3 \mathrm{ha}^{-1}$ respectively. While the mean tree volume for the year 1990-99 was $79.34 \mathrm{~m}^{3} \mathrm{ha}^{-1}$ in Abies pinbrow Fir), Picea smithiana (spruce), Cedrus deodara (deodar), Pinus gerardiana (Chilghosa Pine) and Pinus wallichina (Kail contributed 30.42, 15.42, 7.1, 2.7.9 and $23.61 \mathrm{~m} 3 \mathrm{ha}^{-1}$ respectively. The mean volume investigated during 2012 was $49.77 \mathrm{~m} 3$ ha $^{-1}$ in which Abies pinbrow Fir), Picea smithiana (spruce), Cedrus deodara (deodar), Pinus gerardiana (Chilghosa Pine) and Pinus wallichina (Kail contributed $19.08,8.13,5.30,1.77$ and 15.49 respectively (Figure 6).

Volume of $\left(\mathrm{m}^{3} \mathrm{ha}^{-1}\right)$ mentioned in the previous studies is also consistent with the findings of the present study.

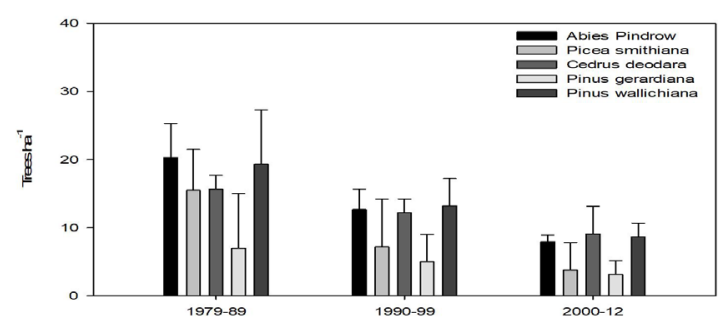

Figure 5. Dynamics of tree density (trees ha ${ }^{-1}$ ) of all dominant species during 1979 to 2012.

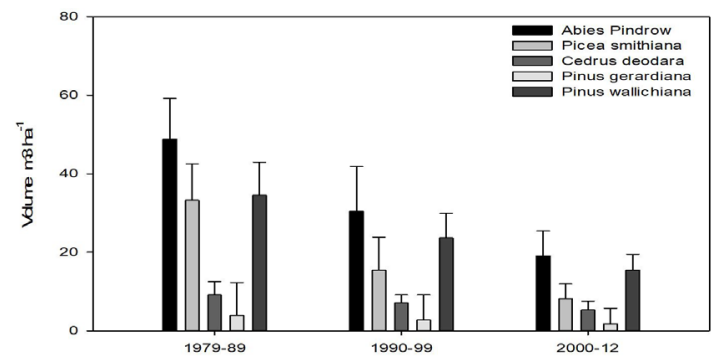

Figure 6. Dynamics of tree volume ( $\mathrm{m} 3$ ha-1) of all dominant species during 1979 to 2012.
The mean maximum volume to dominant tree species Kail, Fir, Deodar and Chilgoza trees was 1.92, 1.57, 0.46 and $0.291 \mathrm{~m}^{3}$.tree ${ }^{-1}$ respectively while the mean minimum volume in all the species was $0.025,0.016,0.020$ and $0.004 \mathrm{~m}^{3} \cdot$ tree $^{-1}$ respectively (Abdul et al., 2014). This study revealed significant difference $(\mathrm{P}<0.001)$ for the volume among all the species during different time. However the total productivity in this ecosystem was recorded as 4-8 $\mathrm{m}^{3} \mathrm{ha}^{-1} \mathrm{yr}^{-1}$ (Sheikh, 1993).

\subsubsection{Tree biomass}

The total biomass during the year 1979-89 was $38.80 \mathrm{t}$ $\mathrm{ha}^{-1}$ and it decreased to 23.81 and $15.05 \mathrm{t} \mathrm{ha}^{-1}$ respectively for 1990-99 and 2000-2012. The mean biomass exhibited species wise during the year 1979-89 was 18.17, 14.94, 5.10, 2.18, $16.58 \mathrm{t} \mathrm{ha}^{-1}$ respectively by Abies pinbrow Fir), Picea smithiana (spruce), Cedrus deodara (deodar), Pinus gerardiana (Chilghosa Pine) and Pinus wallichina (Kail). While the mean biomass exhibited species wise during the year 1990-99 was $11.31,6.93,3.97,1.65,11.33$ t ha $^{-1}$ respectively by Abies pinbrow (Fir), Picea smithiana (spruce), Cedrus deodara (deodar), Pinus gerardiana (Chilghosa Pine) and Pinus wallichina (Kail). The inventory of the forest revealed that mean biomass exhibited by tree species during the year 2000-2012 was 7.09, 5.63, 2.98, 1.77 and $7.43 \mathrm{t} \mathrm{ha}^{-1}$ from Abies pinbrow Fir), Picea smithiana (spruce), Cedrus deodara (deodar), Pinus gerardiana (Chilghosa Pine) and Pinus wallichina (Kail respectively (Figure 7). More over this biomass was significantly different $(\mathrm{P}<0.001)$ for all the species. Ali et al. (2005) prepared the biomass tables for dominant species of the region and mentioned a deodar, kail. Fir and spruce tree of $52 \mathrm{~cm}$ diameter have a total biomass of 5.6, 5.1, 2.8 and 4.1 tones. Value $\mathrm{R}^{2}=0.92$ as shown in

\subsubsection{Dynamics of C stocks}

This study revealed that in 1979- 89 the total above ground C stocks were $19.40 \mathrm{t} \mathrm{ha}^{-1}$ while these stocks showed decreasing trend with the change in land use and reached up to 11.90 and $7.52 \mathrm{t} \mathrm{ha}^{-1}$ during the year 1990-99 and 2000-12. The mean C stocks exhibited by dominant tree species during the year 1979-89 was 9.08, 7.47, 2.55, 1.09, $8.09 \mathrm{t} \mathrm{ha}^{-1}$ respectively by Abies pinbrow Fir), Picea smithiana (spruce), Cedrus deodara (deodar), Pinus gerardiana (Chilghosa Pine) and Pinus wallichina (Kail). While the total above ground C stocks exhibited species wise during the year 1990-99 was 7.09, 5.65, 1.99, 1.56, $5.66 \mathrm{t} \mathrm{ha}^{-1}$ respectively by Abies pinbrow Fir), Picea smithiana (spruce), Cedrus deodara (deodar), Pinus

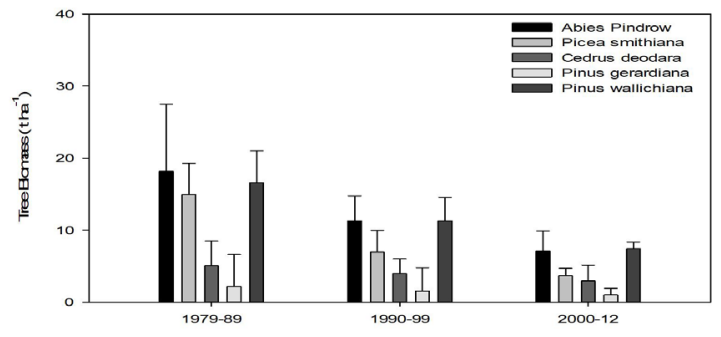

Figure 7. Dynamics of tree biomass (t ha-1) during 1979-2012. 
gerardiana (Chilghosa Pine) and Pinus wallichina (Kail. SThe student t-test revealed the significant difference $(\mathrm{P}<0.001)$ in $\mathrm{C}$ stock dynamics among the all the species during different time periods.

The inventory of the forest revealed that total above ground biomass exhibited by tree species during the year 2000-2012 was 3.54, 2.12, 1.48, 0.49 and $3.71 \mathrm{t} \mathrm{ha}^{-1}$ from Abies pinbrow (Fir), Picea smithiana (spruce), Cedrus deodara (deodar), Pinus gerardiana (Chilghosa Pine) and Pinus wallichina (Kail) respectively (Figure 8). Anwar, 2015b mentioned that the total carbon $t^{\text {tree }}{ }^{-1}$ of dominant species of the region including deodar, kail. Fir and spruce have 2.6, $2.4,1.3$ and 1.9 tree $^{-1}$ having diameter of $52 \mathrm{~cm}$ respectively.

\subsection{To determine the potential of carbon sequestration of} the dominant tree species for the next 100 years

In this study simulation of the $\mathrm{C}$ stocks of Forest land use of the research area was determined using $\mathrm{CO}_{2}$ Fix ver. 3.2 Model. For this purpose consolidated c stocks simulation as well as simulation for $\mathrm{C}$ stocks of dominant $\mathrm{t}$ tree species was carried out.

\subsubsection{Simulation of biomass $C$ stocks of the dominant tree species}

The simulation of the $C$ stocks in biomass of each dominant tree species revealed that a total of 19.0, 6.66, 8.16, 5.44 and $8.43 \mathrm{MgC} \mathrm{ha}{ }^{-1}$ would be contributed by Abies pinbrow (Fir), Picea smithiana (spruce), Cedrus deodara (deodar), Pinus gerardiana (Chilghosa Pine) and Pinus wallichina (Kail) respectively in the year 2112 under business as usual scenario (Figure 9).

\subsubsection{Simulation of soil C stocks}

The simulation of the $\mathrm{C}$ stocks in soils of these forest ecosystems revealed to the total $\mathrm{C}$ stocks in the soils would increase from $0.63 \mathrm{Mg} \mathrm{C}^{-1}$ in the year 2012 to $4.82 \mathrm{Mg} \mathrm{C} \mathrm{ha}^{-1}$ in the year 2012 as can be seen in Table 6 . The regression analysis revealed a quadratic relationship between simulation years and the soil $\mathrm{C}$ stocks with co-efficient of determination value $\mathrm{R}^{2}=0.96$ (Figure 10).

\subsubsection{Simulation of total C stocks in entire forest ecosystem}

The simulation results indicated that total $C$ stocks in forest land use for the next 100 year years (2012-2112)

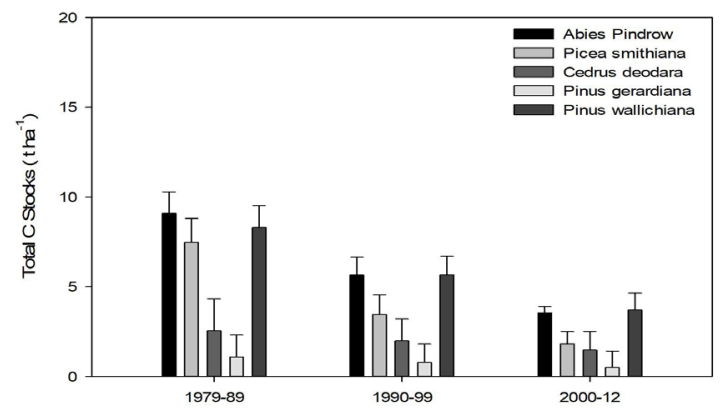

Figure 8. Dynamics of total $C$ stocks ( $t$ ha- 1 ) in vegetation biomass during 1979-2012. would change from 4.63 $\mathrm{Mg} \mathrm{Cha-1}$ (including all species) to $71.79 \mathrm{Mg} \mathrm{Cha}^{-1}$ with the assumption of business as usual for this land use. The biomass carbon would change from 1.48 $\mathrm{Mg} \mathrm{C} \mathrm{ha}^{-1}$ to $47.25 \mathrm{Mg} \mathrm{C}^{-1}$ during 2012 to 2112. The contribution of $\mathrm{C}$ stocks from soil is $0.63 \mathrm{Mg} \mathrm{C} \mathrm{ha}^{-1}$ in the year 2012 and this would increase to $4.82 \mathrm{Mg} \mathrm{Cha}^{-1}$ in the year 2112 as can be seen in Figure 11.The student t-test show significant difference $(\mathrm{P}<0.001)$ of $\mathrm{C}$ stocks for all the species during different time periods. The regression analysis showed a linear relationship between total $C$ stocks of the ecosystem and the simulation (years) with co-efficient of determination.

\subsubsection{Carbon sequestration potential/rate of input of carbon in forest ecosystem}

The study revealed that $\mathrm{C}$ stocks of the biomass and the soil as well as the total C stocks of the ecosystem increased with the increasing age. Species wise rate of input of carbon/ C sequestration has been showed in Figure 12-16 for Abies pinbrow Fir), Picea smithiana (spruce), Cedrus deodara (deodar), Pinus gerardiana (Chilghosa Pine) and Pinus wallichina (Kail) respectively. The $\mathrm{C}$ stocks of biomass would increase from 1.47 to $47.69 \mathrm{Mg} \mathrm{C}^{-1}$ at a rate of $0.466 \mathrm{Mg}$ $\mathrm{C} \mathrm{ha}^{-1} \mathrm{yr}^{-1}$, while the $\mathrm{C}$ stocks of soil would increase from 0.63 to $4.82 \mathrm{Mg} \mathrm{Cha}^{-1}$ at rate (C sequestration) of $0.04 \mathrm{Mg}$ $\mathrm{C} \mathrm{ha}^{-1} \mathrm{yr}^{-1}$ respectively. The total $\mathrm{C}$ stocks of ecosystem was $4.62 \mathrm{Mg} \mathrm{C} \mathrm{ha}^{-1}$ in the year 2012 and it increase to 71.70 $\mathrm{Mg} \mathrm{C} \mathrm{ha-1} \mathrm{with} \mathrm{an} \mathrm{annual} \mathrm{input} \mathrm{(} \mathrm{C}$ sequestration) of $\mathrm{C}$ at a rate of $0.67 \mathrm{MgC}$ ha-1 $\mathrm{yr}^{-1}$ (Figure 17).

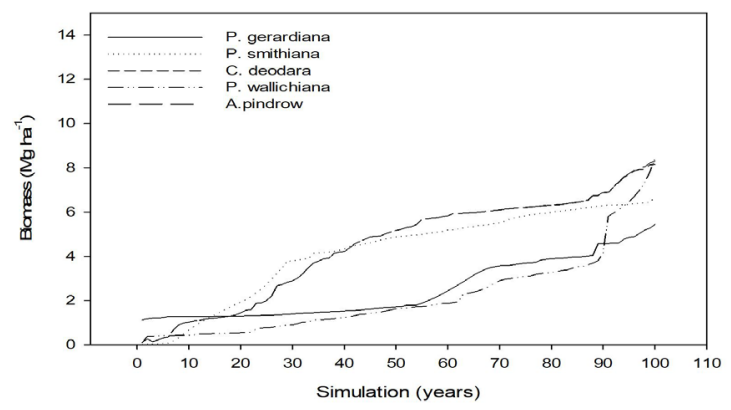

Figure 9. Simulations of biomass $\mathrm{C}$ stocks $\left(\mathrm{Mg} \mathrm{C} \mathrm{ha}^{-1}\right)$ in all the species.

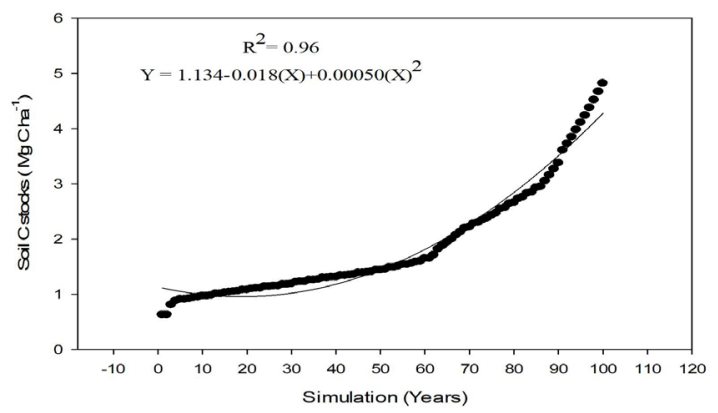

Figure 10. Simulation of $\mathrm{C}$ stocks ( $\mathrm{Mg} \mathrm{C}$ ha-1) in soil of these forest ecosystems. 
Table 6. Soil carbon stocks.

\begin{tabular}{|c|c|c|c|c|c|}
\hline S.No & Name of place & Comportment no & Depth range & Organic matter & Carbon stock \\
\hline 1 & Fairy meadow & C3 & $16-30$ & 1.20 & 0.696 \\
\hline 2 & Thore & C3 & $0-15$ & 1.25 & 0.725 \\
\hline 3 & G. abad & $\mathrm{C} 1$ & $15-30$ & 1.35 & 0.783 \\
\hline 4 & Fairy meadow & C3 & $0-15$ & 1.10 & 0.638 \\
\hline 5 & G. abad & $\mathrm{C} 2$ & $0-15$ & 1.50 & 0.870 \\
\hline 6 & Fairy meadow & $\mathrm{C} 2$ & $16-30$ & 1.25 & 0.725 \\
\hline 7 & G.abad & $\mathrm{C} 2$ & $16-30$ & 1.10 & 0.638 \\
\hline 8 & G.abad & $\mathrm{C} 1$ & $0-15$ & 1.15 & 0.667 \\
\hline 9 & Botogah & $\mathrm{C} 1$ & $0-15$ & 1.21 & 0.702 \\
\hline 10 & Thore & $\mathrm{C} 2$ & $15-30$ & 1.25 & 0.725 \\
\hline 11 & Thore & C3 & $15-30$ & 1.20 & 0.696 \\
\hline 12 & Thore & $\mathrm{C} 1$ & $15-30$ & 1.18 & 0.684 \\
\hline 13 & Botogah & $\mathrm{C} 2$ & $0-15$ & 1.32 & 0.766 \\
\hline 14 & Bobsar limit & C3 & $0-15$ & 1.33 & 0.771 \\
\hline 15 & Thore & $\mathrm{C} 2$ & $0-15$ & 1.26 & 0.731 \\
\hline 16 & Bobsar limit & C3 & $15-30$ & 1.18 & 0.684 \\
\hline 17 & Botogah & $\mathrm{C} 2$ & $15-30$ & 1.15 & 0.667 \\
\hline 18 & Bobsar limit & $\mathrm{C} 1$ & $15-30$ & 1.21 & 0.702 \\
\hline 19 & Botogah & $\mathrm{C} 1$ & $15-30$ & 1.17 & 0.679 \\
\hline 20 & Bobusar limit & $\mathrm{C} 2$ & $15-30$ & 1.12 & 0.650 \\
\hline 21 & Thore & $\mathrm{C} 1$ & $0-15$ & 1.10 & 0.638 \\
\hline 22 & Bobsar & $\mathrm{C} 1$ & $0-15$ & 1.21 & 0.702 \\
\hline 23 & Bobsar limit & $\mathrm{C} 2$ & $0-15$ & 1.13 & 0.655 \\
\hline 24 & Fairy meadow & $\mathrm{C} 1$ & $0-15$ & 1.18 & 0.684 \\
\hline 25 & Fairy meadow & $\mathrm{C} 2$ & $15-30$ & 1.22 & 0.708 \\
\hline 26 & Fairy meadow & C3 & $0-15$ & 1.33 & 0.771 \\
\hline 27 & G. abad & C3 & $0-15$ & 1.52 & 0.881 \\
\hline 28 & G. abad & C3 & $15-30$ & 1.38 & 0.800 \\
\hline 29 & Botoghah & C3 & $0-15$ & 1.34 & 0.777 \\
\hline 30 & Botoghah & C3 & $15-30$ & 1.26 & 0.730 \\
\hline 31 & Hudur & $\mathrm{C} 1$ & $0-15$ & 1.20 & 0.696 \\
\hline 32 & Hudur & $\mathrm{C} 2$ & $15-30$ & 1.22 & 0.707 \\
\hline 33 & Hudur & C3 & $0-15$ & 1.35 & 0.783 \\
\hline 34 & Hudur & $\mathrm{C} 2$ & $0-15$ & 1.30 & 0.754 \\
\hline 35 & Hudur & $\mathrm{C} 1$ & $15-30$ & 1.15 & 0.667 \\
\hline 36 & Hudur & C3 & $15-30$ & 1.24 & 0.719 \\
\hline
\end{tabular}

Total carbon found in soil= 25.871. Fairy medow=4.222, Thore=4.199, Ghorabad=4.639, Botoghah=4.321, Babusor=4.164, Hudur=4.326. 


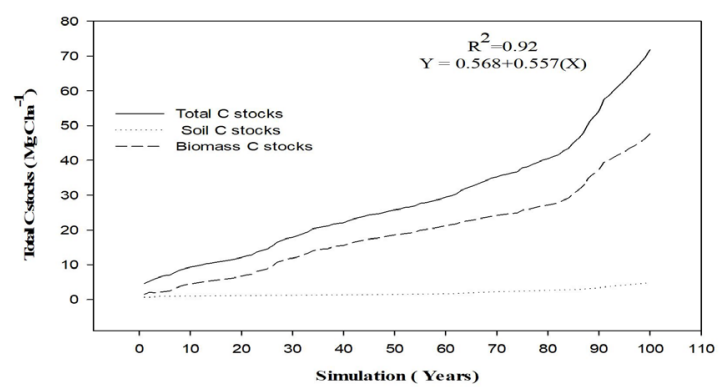

Figure 11. Simulation of total C stocks in entire ecosystem.

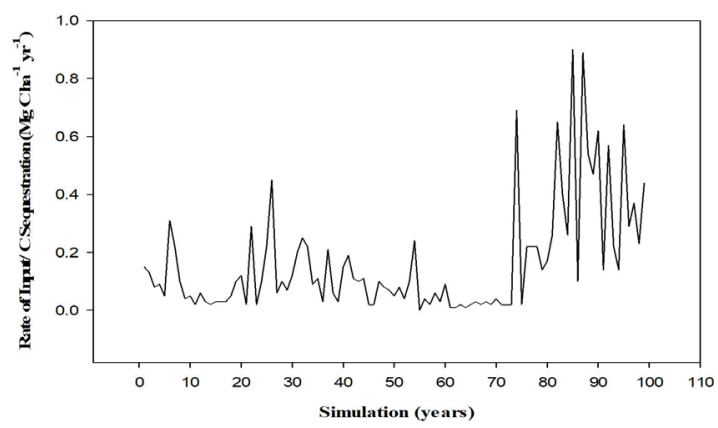

Figure 12. Rate of input of $\mathrm{C} / \mathrm{C}$ sequestration $\left(\mathrm{Mg} \mathrm{C} \mathrm{ha-1}^{-1} \mathrm{yr}^{-1}\right)$ in Abies pindrow.

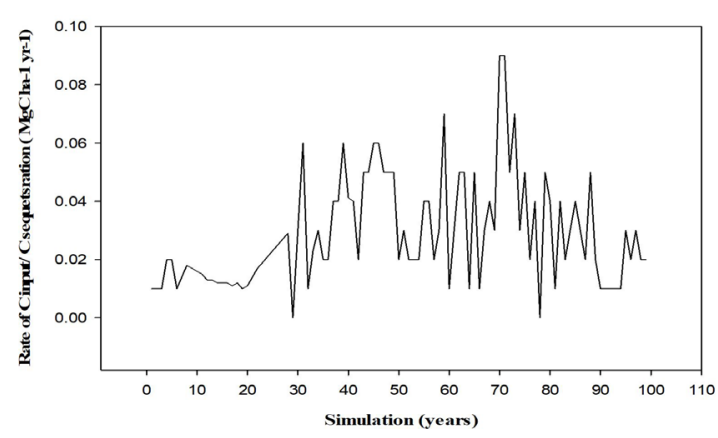

Figure 13. Rate of input of $C$ / $C$ sequestration ( $M g$ C ha-1 $\mathrm{yr}-1$ ) in Picea Smithiana (Wall) Boiss.

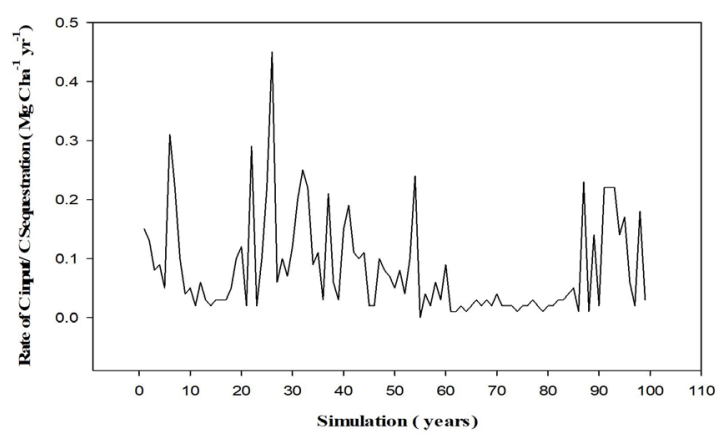

Figure 14. Rate of input of $\mathrm{C} / \mathrm{C}$ sequestration $\left(\mathrm{Mg} \mathrm{Cha}^{-1} \mathrm{yr}^{-1}\right)$ in Cedrus deodara (Roxb. Ex Lamb) G. Don.

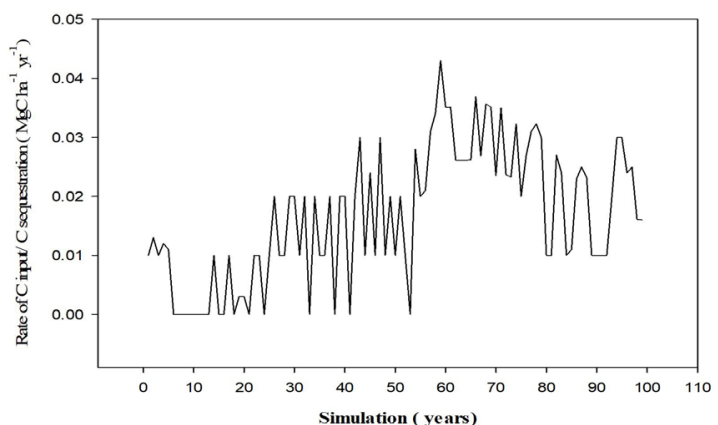

Figure 15. Rate of input of $\mathrm{C} / \mathrm{C}$ sequestration $(\mathrm{Mg} \mathrm{C}$ ha- $-1 \mathrm{yr}-1)$ in Pinus gerardiana Wall. Ex Lamb.

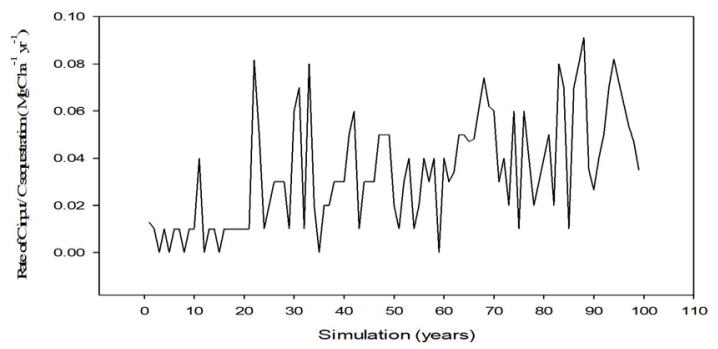

Figure 16. Rate of input of $\mathrm{C} / \mathrm{C}$ sequestration ( $\mathrm{Mg} \mathrm{C}$ ha-1 $\mathrm{yr}-1)$ in Pinus wallichiana A. B. Jackson.

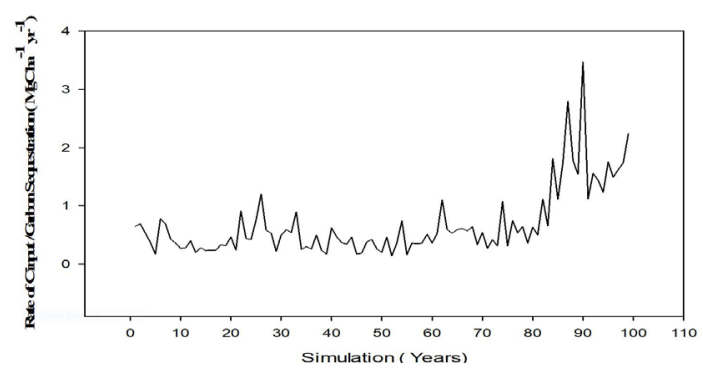

Figure 17. Rate of input of $\mathrm{C} / \mathrm{C}$ sequestration (( $\mathrm{Mg} \mathrm{C}$ ha-1 $\mathrm{yr}-1)$ in entire ecosystem

\section{Conclusion and Recommendation}

The study results revealed a decrease in both forest and snow cover in the region from 1979-2012 while agricultural, grassland /bushes land use showed an increasing trend during this time. During 1979- 89 the total above ground C stocks were $19.40 \mathrm{Mg} \mathrm{C}^{-1}$ while these stocks showed decreasing trend with the change in land use and reached up to 11.90 and $7.52 \mathrm{Mg} \mathrm{C}$ ha $^{-1}$ during the year $1990-99$ and 2000-12. The simulation of C stocks showed a total of 19.0, 6.66, 8.16, 5.44 and $8.43 \mathrm{MgC} \mathrm{ha}^{-1}$ would be contributed by Abies pindrow (FIR), Picea smithiana (spruce), Cedrus deodara (deodar), Pinus gerardiana (Chilghosa Pine) and Pinus wallichiana (Kail) respectively in the year 2112 under business as usual scenario for the next 100 years. The study highlights the effects of change in forest cover percentage 
(usually decreasing trend) which is the subject that would attain more attention of the forest managers and policy makers. Physiologically, the study district is part of the northern Pakistan ideally situated at the junction of three mountains system namely HinduKush, Karakoram and Himalaya. Here many developmental endeavors, including the construction of the proposed Diamer- Basha Dam, are currently taking place. Gearing to these development, the results of the study can be helpful in analyzing the future impacts of these developments on these land cover and $C$ stocks in the forest ecosystem. It is highly recommended to control land use change, protect forest, control snow cover and control on entire ecosystem from damaging. We need further more like project such as BTAP and green Pakistan project to increase the forest cover.

\section{References}

ABDUL, R., NIZAMI, S. M., SALEEM, A. and HANIF, M., 2014. Characteristics and growing stocks volume of forest stand in dry temperate forest of Chilas gilgit-baltistan. Open Journal of Forestry, vol. 4, no. 3, pp. 231-238.

ADNAN, A., MIRZA, S.M. and NIZAMI, S.M., 2014. Assessment of biomass and carbon stocks in coniferous forest of Dir Kohistan, KPK. Pakistan Journal of Agricultural Sciences, vol. 51, no. 2, pp. 345-350.

ALAM, K. and NIZAMI S. M. , 2014. Assessing biomass expension factorof birch tree Betula Utilis D. Don. Open Jornal of Forestry, vol. 4, no. 3, pp. 181-190.

ALI, J. and BENJAMINSEN, T.A., 2004. Fuelwood, timber and deforestation in the Himalayas. Mountain Research and Development, vol. 24, no. 4, pp. 312-318. http://dx.doi. org/10.1659/0276-4741(2004)024[0312:FTADIT]2.0.CO;2.

ALI, J., BENJAMINSEN, T.A., HAMMAD, A.A. and DICK, Ø.B., 2005 The road to deforestation: an assessment of forest loss and its causes in Basho Valley, Northern Pakistan. Global Environmental Change, vol. 15, no. 4, pp. 370-380. http://dx.doi.org/10.1016/j. gloenvcha.2005.06.004.

ALLISON, L., 1965. Organic carbon. Methods of soil analysis: Part 2 Chemical and microbiological properties, vol. 9, 1367-1378.

ALQURASHI, A.F. and KUMAR, L., 2014. Land use and land cover change detection in the Saudi Arabian desert cities of Makkah and Al-Taif using satellite data. Advances in Remote Sensing, vol. 3, no. 03, pp. 106-119. http://dx.doi.org/10.4236/ars.2014.33009.

ANDERSON, J.M. and INGRAM, J.S.I., 1993. Tropical soil biology and fertility. Wllingford: $C A B$ International.

ANWAR, A., 2015a. Biomas and carbon table for major tree species of Gilgit Baltistan. Peshawar: Pakistan Forest Institute, 42 p.

ANWAR, A., 2015b. Local volume table of conifer species for Gilgit Baltistan. Peshawer: Pakistan Forest Institute, 38 p.

ARAI, K. and BU, X.Q., 2007. ISODATA clustering with parameter (threshold for merge and split) estimation based on GA: Genetic Algorithm. Reports of the Faculty of Science and Engineering. Saga University, vol. 36, pp. 17-23.

BASAVARAJAPPA, H.T., PUSHPAVATHI, K.N. and MANJUNATHA, M.C., 2015. Land use/land classification analysis and soil conservation in precambrian terrain of Chamarajanagara District, Karnataka, India using geomatics application. International Journal of Science. Engineering and Technology, vol. 3, no. 3, pp. 739-747.

BISHT, B.S. and KOTHYARI, B.P., 2001. Landcover change analysis of garur gangawatershed using GIS/Remote Sensing technique.
Photonirvachak (Dehra Dun), vol. 29, no. 3, pp. 137-141. http:// dx.doi.org/10.1007/BF02989925.

BRIASSOULIS, H., 2009. Factors influencing land-use and land-cover change. In: W.H. VERHEY, ed. Encyclopedia of land use, land cover and soil sciences: land cover, land use and the global change. Oxford: UNESCO/EOLSS, vol. 1, pp. 126-146.

BROWN, S., GILLESPIE, A.J. and LUGO, A.E., 1989. Biomass estimation methods for tropical forests with applications to forest inventory data. Forest Science, vol. 35, no. 4, pp. 881-902.

BROWN, S. and LUGO, A.E., 1982. The storage and production of organic matter in tropical forests and their role in the global carbon cycle. Biotropica, pp. 161-187.

BUTT, A., SHABBIR, R., AHMAD, S.S. and AZIZ, N., 2015. Land use change mapping and analysis using Remote Sensing and GIS: a case study of Simly watershed, Islamabad, Pakistan. The Egyptian Journal of Remote Sensing and Space Sciences, vol. 18, no. 2, pp. 251-259. http://dx.doi.org/10.1016/j.ejrs.2015.07.003.

CHAKRABORTY, D., DUTTA, D. and CHANDRASEKHARAN, H., 2001. Land use indicators of a watershed in arid region, western Rajasthan using Remote Sensing and GIS. Photonirvachak (Dehra Dun), vol. 29, no. 3, pp. 115-128. http://dx.doi.org/10.1007/ BF02989923.

CHAMPION, S.H., SETH, S.K. and KHATTAK, G.M., 1965. Forest types of Pakistan. Peshawar: Pakistan Forest Institute.

DHAKAL, B., SUBEDI, S., KHANAL, B. and DEVKOTA, N.R., 2019. Assessment of major feed resources and its utilization in Manaslu Conservation Area (MCA), Nepal.Journal of Agriculture and Forestry University, vol. 3, pp. 133.

ERB, K.H., GAUBE, V., KRAUSMANN, F., PLUTZAR, C., BONDEAU, A. and HABERL, H., 2007. A comprehensive global 5 min resolution land-use data set for the year 2000 consistent with national census data. Journal of Land Use Science, vol. 2, no. 3, pp. 191224. http://dx.doi.org/10.1080/17474230701622981.

ESRI, 2009. ArcGIS desktop: release 9 [software]. Redlands: Environemental system Research Intstitute.

FANG, J., YU, G., LIU, L., HU, S. and CHAPIN III, F.S., 2018. Climate change, human impacts, and carbon sequestration in China. Proceedings of the National Academy of Sciences of the United States of America, vol. 115, no. 16, pp. 4015-4020. http://dx.doi. org/10.1073/pnas.1700304115. PMid:29666313.

FAO, 2001. Global forest resources assessment 2000: main report. Rome: FAO, 479 p. FAO Forestry Paper, no. 140

GALLANT, A.L., LOVELAND, T.R., SOHL, T.L. and NAPTON, D.E., 2004. Using a geographic framework for analyzing land cover issues. Envi. Man., vol. 34, pp. 89-110.

GAUTAM, A.P., WEBB, E.L., SHIVAKOTI, G.P. and ZOEBISCH, M.A., 2003. Land use dynamics and landscape change pattern in a mountain watershed in Nepal. Agriculture, Ecosystems E Environment, vol. 99, no. 1-3, pp. 83-96. http://dx.doi. org/10.1016/S0167-8809(03)00148-8.

GILLESPIE, T.W., FOODY, G.M., ROCCHINI, D., GIORGI, A.P. and SAATCHI, S., 2008. Measuring and modeling biodiversity from space. Progress in Physical Geography, vol. 32, no. 2, pp. 203-221. http://dx.doi.org/10.1177/0309133308093606.

GOP - Government of Pakistan, 1991. The Pakistan National conservation strategy, the world conservation union (IUCN), Karachi, Pakistan: structure and dynamics. Turk. J. Bat., vol. 35, pp. 419-438.

GROOT, R.S., ALKEMADE, R., BRAAT, L., HEIN, L. and WILLEMEN, L., 2010. Challenges in integrating the concept of ecosystem services and values in landscape planning, management and 
decision making. Ecological Complexity, vol. 7, no. 3, pp. 260-272. http://dx.doi.org/10.1016/j.ecocom.2009.10.006.

HARIPRIYA, G.S., 2000. Estimates of biomass in Indian forests. Biomass and Bioenergy, vol. 19, no. 4, pp. 245-258. http://dx.doi. org/10.1016/S0961-9534(00)00040-4.

HU, M., LI, Z., WANG, Y., JIAO, M., LI, M. and XIA, B., 2019. Spatiotemporal changes in ecosystem service value in response to land-use/cover changes in the Pearl River Delta. Resources, Conservation and Recycling, vol. 149, pp. 106-114. http://dx.doi. org/10.1016/j.resconrec.2019.05.032.

HUA AK., 2017. Land use land cover changes in detection of water quality: a study based on remote sensing and multivariate statistics. Journal of Environmental and Public Health, vol. 2017, 7515130.

IPCC - National Greenhouse Gas Inventories Programme, 2003. Good practice guidance for land use, land-use change and forestry. Kanagawa: Inistitute for Global Environmental Strategies. 590 p .

IQBAL, M., 1982. Working scheme of district Diamer Forest department Northeren Pakistan. GB Forest and wildlife department: Government of Gilgit Baltistan Pakistan, 150 p.

IQBAL, M., 2001. Working plan of district Diamer Forest department Gilgit Bltistan. GB Forest and wildlife department: Government of Gilgit Baltistan Pakistan, 204 p.

IUCN - The World Conservation Union, 2002 [viewed 16 July 2004]. Environmental issues. [online]. Available from: www. edu.sdnpk.org/edu/land.htm.

JOHNSON, W.C. and SHARPE, D.M., 1983. The ratio of total to merchantable forest biomass and its application to the global carbon budget. Canadian Journal of Research, vol. 13, no. 3, pp. 372-383. http://dx.doi.org/10.1139/x83-056

KLEEMANN, J., BAYSAL, G., BULLEY, H.N. and FÜRST, C., 2017. Assessing driving forces of land use and land cover change by a mixed-method approach in north-eastern Ghana, West Africa. Journal of Environmental Management, vol. 196, pp. 411-442. http://dx.doi.org/10.1016/j.jenvman.2017.01.053. PMid:28334680.

KUMAR, A. and PANDEY, A.C., 2013. Evaluating Impact of coal mining activity on landuse/landcover using temporal satellite images in South Karanpura coalfields and environs, Jharkhand State, India. International Journal of Advanced Remote Sensing and GIS, vol. 2, no. 1, pp. 183-197.

LAMICHHANE, B.R. (2008). Dynamics forces of land use/forest cover changes and indicators of climate change in a mountain subwatershed of Gorka. Pokhara: Tribuvan University, Institute of Forestry, $64 \mathrm{p}$. Thesis for Master of Sciences in Natural Resource Management and Rural Development.

LUGO, A.E. and BROWN, S., 1992. Tropical forests as sinks of atmospheric carbon. Forest Ecology and Management, vol. 54, no. 1-4, pp. 239-255. http://dx.doi.org/10.1016/03781127(92)90016-3.

LUNETTA, R.S., KNIGHT, J.F., EDIRIWICKREMA, J., LYON, J.G. and WORTHY, L.D., 2006. Land-cover change detection using multitemporal MODIS NDVI data. Remote Sensing of Environment, vol. 105, no. 2, pp. 142-154. http://dx.doi.org/10.1016/j. rse.2006.06.018.

MALHI, Y., BALDOCCHI, D.D. and JARVIS, P.G., 1999. The carbon balance of tropical, temperate and boreal forests. Plant, Cell E Environment, vol. 22, no. 6, pp. 715-740. http://dx.doi. $\operatorname{org} / 10.1046 / \mathrm{j} .1365-3040.1999 .00453 . x$.

MISHRA V.N., RAI P.K., KUMAR P., and PRASAD R., 2016 Evaluation of land use/land cover classification accuracy using multiresolution remote sensing images. Forum geografic Studii și cercetări de geografie și protecția mediului, vol. XV, no. 1, pp. 45-53.
MUÑOZ-ROJAS, M.M., ROSA, D.D.L., ZAVALA, L.M., JORDAN, A. and ANAYA-ROMERO, M.A., 2011. Changes in land cover and vegetation carbon stocks in Andalusia, Southern Spain. The Science of the Total Environment, vol. 409, no. 14, pp. 27962806. http://dx.doi.org/10.1016/j.scitotenv.2011.04.009. PMid:21531444.

NELSON, G.C. and GEOGHEGAN, J., 2002. Deforestation and land use change: sparse data environments. Agricultural Economics, vol. 27, no. 3, pp. 201-210. http://dx.doi.org/10.1111/j.1574-0862.2002. tb00117.x.

NIZAMI, S.M., 2010. Estimation of carbon stocks in subtropical managed and unmanaged forests of Pakistan. Rawalpindi: Arid Agriculture University Rawalpindi Pakistan, 173 p. A thesis in Forestry and Range Management (doctoral dissertation).

NIZAMI, S.M., 2012. Assessment of the carbon stocks in sub-tropical forests of Pakistan for reporting under Kyoto protocol.Journal of Forestry Research, vol. 23, no. 3, pp. 377-384. http://dx.doi. org/10.1007/s11676-012-0273-1.

OLOKEOGUN, O.S., IYIOLA, K. and IYIOLA, O.F., 2014. Application of remote sensing and GIS in land use/land cover mapping and change detection in Shasha forest reserve, Nigeria. The International Archives of the Photogrammetry, Remote Sensing and Spatial Information Sciences, vol. XL-8, no. 8, pp. 613-616. http://dx.doi.org/10.5194/isprsarchives-XL-8-613-2014.

OZSAHIN, E., DURU, U. and EROGLU, I., 2018. Land use and land cover changes (LULCC), a key to understand soil erosion intensities in the Maritsa Basin. Water (Basel), vol. 10, no. 3, pp. 335. http:// dx.doi.org/10.3390/w10030335.

PERVEZ, W., UDDIN, V., KHAN, S.A. and KHAN, J.A., 2016. Satellitebased land use mapping: comparative analysis of Landsat-8, Advanced Land Imager, and big data Hyperion imagery. Journal of Applied Remote Sensing, vol. 10, no. 2, pp. 10. http://dx.doi. org/10.1117/1.JRS.10.026004.

PHILLIP, M.S., 1994. Measuring trees and forests. 2nd end. Wallingford: CABI.

PHOMPILA, C., LEWIS, M., OSTENDORF, B. and CLARKE, K., 2017. Forest cover changes in Lao tropical forests: physical and socio-economic factors are the most important drivers. Land, vol. 6, no. 2, pp. 23. http://dx.doi.org/10.3390/land6020023.

PRELL, C., HUBACEK, K. and REED, M., 2009. Stakeholder analysis and social network analysis in natural resource management. Society E' Natural Resources, vol. 22, no. 6, pp. 501-518. http:// dx.doi.org/10.1080/08941920802199202.

QAMER, F.M., SHEHZAD, K., ABBAS, S., MURTHY, M.S.R., XI, C., GILSNI, H. and BAJRACHARYA, B., 2016. Mapping deforestation and forest degradation patterns in Western Himalaya, Pakistan. Remote Sensing, vol. 8, no. 5, pp. 385-403. http://dx.doi. org/10.3390/rs8050385.

QURESHI, R., KHAN, W.A., BHATTI, G.R., KHAN, B.A.B.A.R., IQBAL, S., AHMAD, M.S., ABID, M. and YAQUB, A., 2011. First report on the biodiversity of Khunjerab National Park, Pakistan. Pakistan Journal of Botany, vol. 43, no. 2, pp. 849-861.

RAI, P.K., VISHWAKARMA, C.A., THAKUR, S., KAMAL, V. and MUKHERJEE, S., 2016. Changing land trajectories: a case study from India using a remote sensing based approach. European Journal of Geography., vol. 7, no. 2, pp. 63-73.

RAYMENT, G.E. and HIGGINSON, F.R., 1992. Australian Laboratory handbook of soil and water chemical method. Port Melbourne: Inkata press, $330 \mathrm{p}$.

REIS, S., 2008. Analyzing land use/land cover changes using remote sensing and GIS in rize, North-East Turkey. Sensors, vol. 8, no. 10, pp. 6188-6202. http://dx.doi.org/10.3390/s8106188. PMid:27873865. 
RIZWAN, K., ABBAS, Y., SALEEM, A., KARIM, F., ABBAS, S., HUSSAIN, E., RASOOL, M.A. and ALI, N., 2015. Baseline ethno-phytological study in Danyore Valley, Gilgit-Baltistan, Pakistan. Journal of Biological and Environmental Sciences, vol. 7, pp. 108-117.

ROY, J., SAUGIER, B. and MOONEY, H.A., 2001. Terrestrial global productivity. Academic, San Diego.

SAJJAD, S., ASHRAF, M.I., AHMAD, A. and RAHMAN, Z., 2016. The bala forest ecosystem of District Jhelum, A potentional carbon sink. Pakistan Journal of Botany, vol. 48, pp. 121-129.

SCHÄDLER, M., BUSCOT, F., KLOTZ, S., REITZ, T., DURKA, W., BUMBERGER, J., MERBACH, I., MICHALSKI, S.G., KIRSCH, K., REMMLER, P., SCHULZ, E. and AUGE, H., 2019. Investigating the consequences of climate change under different land-use regimes: a novel experimental infrastructure. Ecosphere, vol. 10, no. 3, pp. e02635. http://dx.doi.org/10.1002/ecs2.2635.

SCHELHAAS, M.J., VAN ESCH, P.W., GROEN, T.A., JONG, B.H.J., KANNINEN, M., LISKI, J., MASERA, O., MOHREN, G.M.J., NABUURS, G.J., PALOSUO, T., PEDRONI, L., VALLEJO, A. and VILÉN, T. 2004. CO2FIX V 3.1: a modelling framework for quantifying carbon sequestration in forest ecosystems. Wageningen: Alterra.

SHEIKH, M.J., 1993. Trees of Pakistan. Islamabad: Pictorial Printers. $371 \mathrm{p}$.

SLEETER, B.M., SOHL, T.L., LOVELAND, T.R., AUCH, R.F., ACEVEDO, W., DRUMMOND, M.A., SAYLER, K.L. and STEHMAN, S.V., 2013. Land-cover change in the conterminous United States from 1973 to 2000. Global Environmental Change, vol. 23, no. 4, pp. 733-748. http://dx.doi.org/10.1016/j.gloenvcha.2013.03.006.

SOINI, E., 2005. Land use change patterns and livelihood dynamics on the slopes of Mt. Kilimanjaro, Tanzania. Agricultural Systems, vol. 85, no. 3, pp. 306-323. http://dx.doi.org/10.1016/j. agsy.2005.06.013.

SRIVASTAVA, P.K., SINGH, S.K., GUPTA, M., THAKUR, J.K. and MUKHERJEE, S., 2013. Modeling Impact of land use change trajectories on groundwater quality using Remote Sensing and GIS. Environmental Engineering and Management Journal, vol. 12 , no. 12 , pp. 2343-2355. http://dx.doi.org/10.30638/ eemj.2013.287.

SUNDRIYAL, M. and SUNDRIYAL, R., 2004. Wild edible plants of the Sikkim Himalaya: marketing, value addition and implications for management.J. Econ. Bot, vol. 58, no. 2, pp. 300-315. http://dx.doi. org/10.1663/0013-0001(2004)058[0300:WEPOTS]2.0.CO;2.

VERBURG, P.H., SCHOT, P.P., DIJST, M.J. and VELDKAMP, A., 2004. Land use change modelling: current practice and research priorities. GeoJournal, vol. 61, no. 4, pp. 309-324. http://dx.doi. org/10.1007/s10708-004-4946-y.

WANI, N.R. and QAISAR, K.M., 2014. Carbon percent in different components of tree species and soil organic carbon pool under thesies tree species in Kashmir Valley. Current World Environment, vol. 9, no. 1, pp. 174-181. http://dx.doi.org/10.12944/ CWE.9.1.24

YANG, X. and LO, C.P., 2002. Using a time series of satellite imagery to detect land use and land cover changes in the Atlanta, Georgia metropolitan area. International Journal of Remote Sensing, vol. 23, no. 9, pp. 1775-1798. http://dx.doi. org/10.1080/01431160110075802.

YASIR, M., HUI, S., BINGHU, H. and RAHMAN, S.U., 2020. Coastline extraction and land use change analysis using remote sensing (RS) and geographic information system (GIS) technology-A review of the literature. Reviews on Environmental Health, vol. 35, no. 4, pp. 453-460. http://dx.doi.org/10.1515/reveh-2019-0103. PMid:32924382.

YU, D., JIANG, Y., KANG, M., TIAN, Y. and DUAN, J., 2011. Integrated urban land-use planning based on improving ecosystem service: panyu case, in a typical developed area of China. Journal of Urban Planning and Development, vol. 137, no. 4, pp. 448-458. http:// dx.doi.org/10.1061/(ASCE)UP.1943-5444.0000074.

WALKLEY, A. and BLACK, I.A., 1934. An examination of the Degtjareff method for determining soil organic matter and a proposed modification of the chromic acid titration method. Soil Sci., vol. 37, pp. 29-38. 